\title{
The role of nuclear lamin $B 1$ in cell proliferation and senescence
}

\author{
Takeshi Shimi, ${ }^{1}$ Veronika Butin-Israeli, ${ }^{1}$ Stephen A. Adam, ${ }^{1}$ Robert B. Hamanaka, ${ }^{2}$ \\ Anne E. Goldman, ${ }^{1}$ Catherine A. Lucas, ${ }^{1}$ Dale K. Shumaker, ${ }^{1}$ Steven T. Kosak, ${ }^{1}$ Navdeep S. Chandel, ${ }^{2}$ \\ and Robert D. Goldman ${ }^{1,3}$ \\ ${ }^{1}$ Department of Cell and Molecular Biology, ${ }^{2}$ Department of Medicine, Division of Pulmonary and Critical Care Medicine, \\ Feinberg School of Medicine, Northwestern University, Chicago, Illinois 60611, USA
}

\begin{abstract}
Nuclear lamin B1 (LB1) is a major structural component of the nucleus that appears to be involved in the regulation of many nuclear functions. The results of this study demonstrate that LB1 expression in WI-38 cells decreases during cellular senescence. Premature senescence induced by oncogenic Ras also decreases LB1 expression through a retinoblastoma protein $(\mathrm{pRb})$-dependent mechanism. Silencing the expression of LB1 slows cell proliferation and induces premature senescence in WI-38 cells. The effects of LB1 silencing on proliferation require the activation of $\mathrm{p} 53$, but not $\mathrm{pRb}$. However, the induction of premature senescence requires both $\mathrm{p} 53$ and $\mathrm{pRb}$. The proliferation defects induced by silencing LB1 are accompanied by a p53-dependent reduction in mitochondrial reactive oxygen species (ROS), which can be rescued by growth under hypoxic conditions. In contrast to the effects of LB1 silencing, overexpression of LB1 increases the proliferation rate and delays the onset of senescence of WI-38 cells. This overexpression eventually leads to cell cycle arrest at the G1/S boundary. These results demonstrate the importance of LB1 in regulating the proliferation and senescence of human diploid cells through a ROS signaling pathway.
\end{abstract}

[Keywords: lamin B1; ROS; p53; pRb; proliferation; senescence]

Supplemental material is available for this article.

Received September 20, 2011; revised version accepted November 9, 2011.

The nuclear lamina is closely apposed to the inner membrane of the nuclear envelope (NE) and contributes to the size, shape, and mechanical stability of the nucleus. The major structural proteins of the lamina are the A- and B-type nuclear lamins, comprised of lamin A (LA), LC, LB1, and LB2. Although the major fraction of lamins is found in the lamina, they are also located throughout the nucleoplasm (Moir et al. 2000b; Shimi et al. 2008). LA and LC are derived from a single gene (LMNA) by alternative splicing and are expressed only in differentiated cells. LB1 and LB2 are encoded by $L M N B 1$ and $L M N B 2$, respectively, and at least one of the B-type lamins is expressed in all cells throughout development (Dechat et al. 2008). There is growing evidence that the nuclear lamins play important roles in the anchorage of peripheral elements of chromatin, in regulating the organization of chromosome territories, and in gene expression (Kosak et al. 2002; Guelen et al. 2008; Kumaran and Spector 2008; Shimi et al. 2008). The lamins have also been shown to play important roles in DNA replication and repair, RNA

${ }^{3}$ Corresponding author.

E-mail r-goldman@northwestern.edu.

Article published online ahead of print. Article and publication date are online at http://www.genesdev.org/cgi/doi/10.1101/gad.179515.111. polymerase II (Pol II) transcription, and the epigenetic control of chromatin remodeling (Moir et al. 2000a; Spann et al. 2002; Shimi et al. 2008; Shumaker et al. 2008).

All lamins share a common structure, with a conserved $\alpha$-helical central rod domain flanked by globular head and tail domains (Dechat et al. 2008). The central rod domains of two lamins dimerize into in-parallel and in-register coiled-coil structures, which then interact head to tail to form long protofilaments. Lateral interactions between anti-parallel protofilaments, with influence from the head and tail domains, form the higher-order structures found in the nucleus (Kapinos et al. 2010). Using electron microscopy, the lamina in Xenopus oocytes appears as a meshwork of $\sim 10$ - to 15-nm filaments (Aebi et al. 1986). Higher-order LB1 structures organized into meshworks have been seen in mouse cells by immunofluorescence (Schermelleh et al. 2008). Additionally, A- and B-type lamin fibrils form interacting meshworks within the lamina in HeLa cells (Shimi et al. 2008). Support for these interactions has been derived from silencing LB1 expression using shRNA. The loss of LB1 leads to a dramatic increase in the size of the LA/ $\mathrm{C}$ meshwork and induces the formation of LA/C-rich and LB2-deficient NE blebs. These findings demonstrate that LB1 plays an essential role in maintaining normal LA/C and 
LB2 meshwork structures (Shimi et al. 2008). Furthermore, the LA/C-rich NE blebs induced by LB1 silencing contain gene-rich chromatin with low transcriptional activity even though the activated form of Pol II (Pol IIo) is enriched in these regions. This suggests that both A- and B-type lamins are required for properly regulating gene expression (Shimi et al. 2008). Interestingly, the nuclei of cells from patients with diseases caused by mutations in LMNA, such as Hutchinson-Gilford progeria and EmeryDreifuss muscular dystrophy type 2, frequently exhibit alterations in the structural organization of the A- and B-type lamin meshworks and contain NE blebs similar to those induced by silencing LB1 expression /Goldman et al. 2004; Meaburn et al. 2007; Shimi et al. 2008; Taimen et al. 2009).

One of the common features of cultured cells derived from progeria patients bearing different mutations in $L M N A$ is their premature senescence in culture (McClintock et al. 2006; Taimen et al. 2009). Interestingly, LB1 expression, but not LA/C expression, is significantly decreased as progeria cells become senescent (Scaffidi and Misteli 2005; Kandert et al. 2007; Taimen et al. 2009; Liu et al. 2011). However, the physiological significance of reduced LB1 expression in the proliferation and premature senescence of progeria patient cells has not been explored. Additional insights into the functions of nuclear lamins in cell proliferation have been derived from mouse models. Fibroblasts derived from a transgenic mouse model for progeria exhibit premature senescence (Mounkes et al. 2003). Lmna $^{-/-}$mice appear to develop normally, but growth defects such as low body weight and small size become obvious within $4 \mathrm{wk}$ after birth and the mice die by $\sim 8$ wk (Sullivan et al. 1999). In contrast, homozygous mutant $\operatorname{lmnb} 1^{\Delta / \Delta}$ mice die at birth with defects in lung, bone, and brain development (Vergnes et al. 2004; Coffinier et al. 2011). Further examination of these mice revealed that the defects in brain development are likely due to defective neuronal migration (Coffinier et al. 2011). Embryonic $1 m n b 1^{\Delta / \Delta}$ fibroblasts are aneuploid and stop growing prematurely (Vergnes et al. 2004). In the case of Imnb2 $2^{-1-}$ mice, defects in brain development and neuronal migration have also been described (Coffinier et al. 2011), but embryonic $1 m n b 2^{-/-}$fibroblasts appear to proliferate normally (Coffinier et al. 2010). In a different study, mice with the conditional double knockouts of both $L M N B 1$ and $L M N B 2$ in their skin keratinocytes develop normally (Yang et al. 2011). However, forebrainspecific knockout of either LMNB1 or LMNB2 leads to poor forebrain development, and the double knockout results in complete cortical atrophy (Coffinier et al. 2011). These results suggest that proliferation defects induced by the absence of B-type lamins may be specific for particular tissue types.

The findings in mouse models and in human cell lines derived from progeria patients suggest that LB1 expression is coupled to cell proliferation. In this study, we explore the role of LB1 in the proliferation of human diploid fibroblasts (HDFs). The results show that silencing LB1 expression slows proliferation and rapidly induces premature senescence. On the other hand, the overexpression of GFP-LB1 increases the proliferation rate and delays the onset of senescence of HDFs.

\section{Results}

\section{Changes in the expression of LB1 during senescence}

In order to determine whether LB1 expression is correlated with the proliferation state of HDFs, the expression and nuclear organization of A- and B-type lamins were studied in the HDF cell line WI-38. Cell proliferation and lamin expression were examined as a function of cumulative population doublings (PDs), beginning with cells at PD30 and ending when the cells became senescent at PD41. Senescent cells were identified using senescenceassociated $\beta$-galactosidase (SA- $\beta$-gal) activity (Dimri et al. $1995)$, the formation of senescence-associated heterochromatic foci (SAHFs) (Narita et al. 2003), and the absence of BrdU incorporation (Kennedy et al. 2000; Johnson et al. 2004). The percentages of cells positive for SA- $\beta$-gal activity increased from $\sim 1 \%(n=110)$ to $\sim 55 \%(n=413)$ to $\sim 100 \%(n=175)$, SAHFs increased from $\sim 3 \%(n=460)$ to $\sim 32 \%(n=261)$ to $\sim 55 \%(n=264)$, and BrdU incorporation decreased from $\sim 30 \%(n=460)$ to $\sim 11 \%$ ( $n=$ 261) to $0 \%(n=304)$ at PD30, PD39, and PD41, respectively (Fig. 1A). Together, these results showed that in $\sim 45 \mathrm{~d}$, the cells went from actively proliferating to presenescent and finally senescent at PD30, PD39, and PD41. Immunofluorescence revealed that all of the lamins were localized normally in the lamina and nucleoplasm (Fig. 1A). However, by the time of senescence at PD41, LB1 staining was greatly reduced, while no obvious changes in LA/C and LB2 could be detected (Fig. 1A). There was also an obvious increase in cell size at PD41, and the nuclei in the senescent cells were larger and more convoluted than nuclei in actively growing cells.

Quantitative immunoblotting showed that the amount of LB1 decreased by $\sim 80 \%-90 \%$ as cells became senescent over the $45 \mathrm{~d}$ required to progress from PD30 to PD41 (Fig. 1B). The loss of LB1 first became noticeable between PD36 and PD37 (days 19-24), and the amount of LB1 decreased gradually until the majority of cells were senescent at PD41 (day 45) (Fig. 1B, bottom panel). The protein levels of LA/C and LB2 in senescent cells (PD41) remained unchanged compared with actively proliferating cells at PD30 (Fig. 1C). To determine whether the loss of LB1 could be the result of decreased proliferation, PD30 cells were made quiescent by serum starvation for $72 \mathrm{~h}$. Under these conditions, the protein levels of all lamins remained unaltered compared with actively proliferating cells (Fig. 1C). The mRNA levels of $L M N A, L M N B 1$, and $L M N B 2$ were also assayed by quantitative RT-PCR /qRTPCR) at PD30, PD39, and PD41. The LMNB1 transcripts decreased by $\sim 95 \%$ between PD30 and PD41 (Fig. 1D). There were also much smaller decreases in LMNB2 mRNA levels, while the expression of LMNA mRNA appeared to be maintained as cells entered senescence. Together, these results demonstrate that LB1 expression is transcriptionally down-regulated as cells become senescent. 


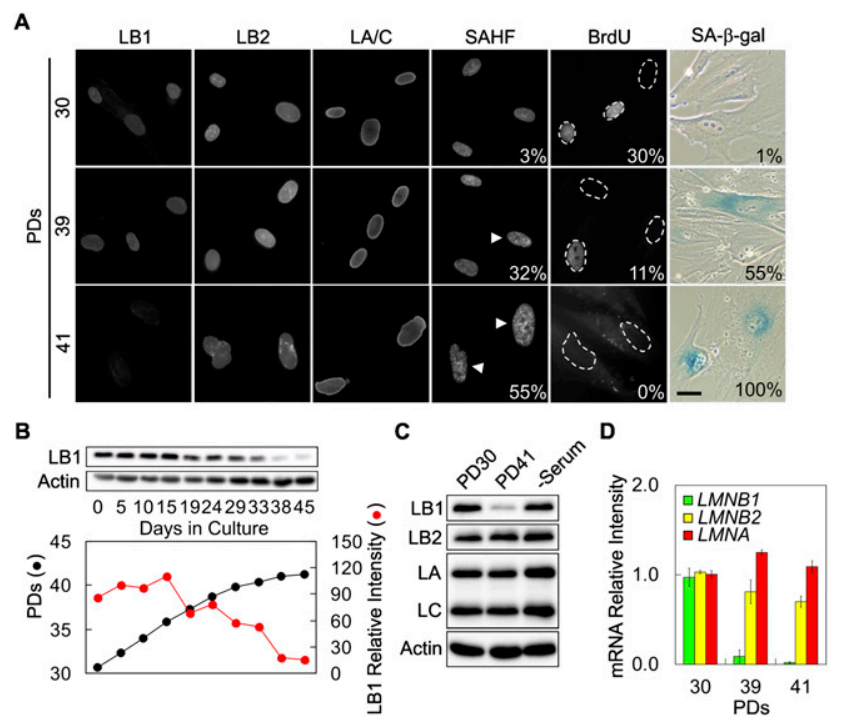

Figure 1. Loss of LB1 is associated with senescence in WI-38 cells. (A) The nuclear localization of LB1, LB2, and LA/C in WI38 cells was examined by immunofluorescence at PD30, PD39, and PD41. Senescent cells were identified by Hoechst staining of SAHFs, SA- $\beta$-gal activity, and BrdU incorporation. The numbers on the panels indicate the percentage of cells positive for the marker indicated at the top of the column. Bar, $20 \mu \mathrm{m}$. ( $B$, top panel) LB1 protein levels were assayed by Western blotting after culture from PD30 to PD41 and quantified (see the Materials and Methods). (Bottom graph) The relationship between PDs (black) and the amount of LB1 (red) is shown. $(C)$ The expression levels of LB1, LB2, and LA/C were examined at PD30 and PD41 and in quiescent cells by immunoblotting. It should be noted that neither pre-LA nor LA $\Delta 50$ progerin were detected in the senescent cells (see the Discussion). Actin was used as a loading control. (D) LMNB1, LMNB2, and LMNA mRNA levels were determined by qPCR at PD30, PD39, and PD41. The error bars represent standard error of the mean $(n=6)$.

Oncogenic Ras induces premature senescence, and the resulting loss of LB1 requires $p R b$

Premature senescence can be induced in HDFs by expression of an active form of oncogenic Ras (RasG12V) (Serrano et al. 1997). The expression of RasG12V in WI38 cells at PD24 induced premature senescence within 7 $\mathrm{d}$ after selection (see the Materials and Methods). At this time, $\sim 88 \%(n=432)$ of the cells were positive for SAHFs versus $\sim 2 \%(n=430)$ in controls transfected with an empty vector $(\mathrm{V}), \sim 83 \%(n=166)$ contained SA- $\beta$-gal versus $\sim 0.6 \%(n=168)$ for $\mathrm{V}$, and $\sim 0.5 \%(n=172)$ incorporated BrdU versus $17 \%(n=674)$ for $\mathrm{V}$. In these prematurely senescent cells, LB1 levels decreased by $\sim 98 \%$, and no substantial changes could be detected in LA/C and LB2 (Fig. 2A). These results showed that the rapid induction of premature senescence by oncogenic Ras is accompanied by a loss of LB1, similar to that seen in spontaneous senescence.

Attempts were then made to identify which of the welldefined pathways leading to senescence were associated with the loss of LB1. The transcription factors p53 and retinoblastoma $(\mathrm{pRb})$ are major regulators of genes involved in the control of cell cycle progression and proliferation (Polager and Ginsberg 2009). In response to the stress induced by oncogenic Ras in HDFs, both the p53 and pRb pathways are activated and mediate the steps involved in senescence (Campisi and d'Adda di Fagagna 2007; Rodier et al. 2011). Therefore, the involvement of each pathway in regulating LB1 expression during senescence was investigated. The $\mathrm{p} 53$ pathway was examined by expressing the dominant-negative mutant $\mathrm{p} 53 \mathrm{DD}$, which inhibits the activation of p53 (Shaulian et al. 1992). In cells stably expressing p53DD, RasG12V expression induced senescence within $7 \mathrm{~d}$ after selection. There was an increase in the number of cells positive for SA- $\beta$-gal $(\sim 65 \%[n=230]$ vs. $\sim 0.6 \%[n=333]$ for controls $[\mathrm{p} 53 \mathrm{DD} / \mathrm{V}])$ and the number of cells positive for SAHFs $(\sim 49 \%[n=268]$ vs. $0 \%[n=386]$ for $\mathrm{p} 53 \mathrm{DD} / \mathrm{V})$, and the number of cells incorporating BrdU decreased $(\sim 19 \%[n=268]$ vs. $\sim 31 \%$ $[n=386]$ for $\mathrm{p} 53 \mathrm{DD} / \mathrm{V})$. At the same time, the level of LB1 decreased by $\sim 98 \%$ (Fig. 2 B), similar to the decrease in LB1 in cells induced to senesce with RasG12V in the absence of p53DD (see Fig. 2A). These results demonstrate that the loss of LB1 in premature senescence induced by RasG12V does not require activation of the p53 pathway.

To examine the role of the $\mathrm{pRb}$ pathway in mediating the decrease in LB1 protein levels during senescence, $\mathrm{pRb}$ was inactivated by expression of the adenovirus E1A oncoprotein (Jones 1990; Serrano et al. 1997). E1A rescues RasG12V-induced senescence by multiple pathways, including overriding the negative effects of the $\mathrm{Rb}$ family on proliferation-associated genes and inhibiting the activation of p53 (Serrano et al. 1997; Deng et al. 2005). Since the previous experiment showed that the p53 pathway is not required for the reduction of LB1 expression induced by RasG12V, E1A expression can be used to test the role of $\mathrm{pRb}$ in the loss of LB1. When either V or the RasG12V vector was expressed in cells stably expressing E1A, the cells did not become senescent, as determined by measuring the accumulation of the senescence markers and BrdU incorporation (Serrano et al. 1997; data not shown). In contrast to the $\sim 98 \%$ reduction in LB1 levels in cells made senescent by expressing RasG12V alone (Fig. 2A), LB1 levels were increased by $\sim 72 \%$ in $\mathrm{E} 1 \mathrm{~A} / \mathrm{RasG} 12 \mathrm{~V}$-expressing cells relative to controls (E1A/V) (Fig. 2B, right lanes). Therefore,

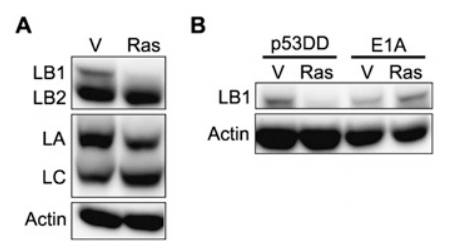

Figure 2. Senescence induced by the expression of oncogenic Ras (RasG12V) results in the down-regulation of LB1. (A) RasG12V (Ras) or an empty vector (V) was expressed at PD24 in WI-38 cells. The expression levels of LB1, LB2, and LA/C in these cells were determined by immunoblotting $7 \mathrm{~d}$ following selection. $(B)$ The expression levels of LB1 were determined after inhibition of either the p53 or pRb pathways by the expression of p53DD or E1A, respectively, followed by the expression of RasG12V to induce senescence (see the Materials and Methods). 
the decrease in LB1 expression during RasG12V-induced senescence is probably due to the action of $\mathrm{pRb}$. These results are consistent with previous studies showing that the E2F family of transcription factors regulates $L M N B 1$ expression (Hallstrom et al. 2008).

\section{LB1 silencing inhibits proliferation and induces premature senescence}

The fact that $L M N B 1$ expression is regulated by E2F transcription factors suggests that LB1 may have an important role in WI-38 cell proliferation. To test this, shRNAs targeted to $L M N B 1$ transcripts (LB1sh) were used to silence LB1 expression in PD24 cells (Shimi et al. 2008). Two shRNA target sequences were examined, and both shRNAs resulted in an $\sim 80 \%-90 \%$ decrease of LB1 at $8 \mathrm{~d}$ following selection, with no obvious changes in the expression levels of LA/C and LB2 (Fig. 3A; Supplemental Fig. S1A). At 12 d, the proliferation rate of LB1 silenced cells was significantly decreased compared with controls with a scrambled sequence (Sc) (Fig. 3B; Supplemental

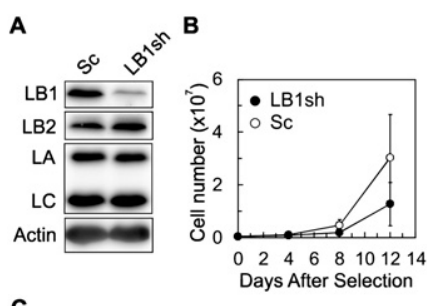

C
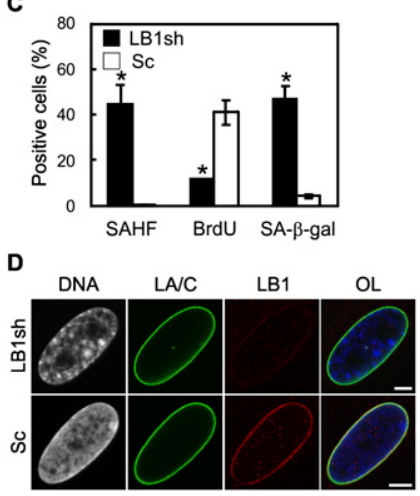

Figure 3. Silencing LB1 induces premature senescence. The effects of silencing LB1 expression on cell proliferation were determined at PD24 in WI-38 cells. (A) The expression levels of LB1, LB2, and LA/C were determined by immunoblotting at $8 \mathrm{~d}$ after selection for the vector expressing the LB1 targeted shRNA (LB1sh-T3; LB1sh) or a scrambled sequence (Sc). (B) Growth curves comparing the proliferation rates of Sc and LB1sh cells compared for $12 \mathrm{~d}$ following selection $\left(n=4{ }^{\prime}\left[{ }^{\star}\right] P=1.4 \times 10^{-4}\right)$. Error bars represent standard deviations. $(C)$ Senescence markers quantified $11 \mathrm{~d}$ following selection. The error bars indicate the standard deviations. There was a significant increase in the percentage of cells containing SAHFs $\left.\left(n=2 ;{ }^{\star}{ }^{\star}\right] P=1.9 \times 10^{-2}\right)$ and SA- $\beta$-gal $\left.\left(n=2 ;{ }^{\star}\right] P=8.8 \times 10^{-3}\right)$ and a decrease in cells incorporating $\operatorname{BrdU}\left(n=2 ;\left[^{\star}\right] P=1.5 \times 10^{-2}\right)$ in LB1 silenced cells. Asterisks indicate statistically significant changes $\left({ }^{\star}\right] P<5.0 \times$ $\left.10^{-2}\right)$. (D) Immunofluorescence of Sc and LB1sh cells. Anti-LA/C (green), anti-LB1 (red), and DNA stained with Hoechst 33258 (white or blue in overlay (OL)) Bar, $5 \mu \mathrm{m}$.
Fig. S1B). A reduction in the rate of proliferation was also seen in another HDF line, IMR-90 (Supplemental Fig. S1C,D), although the effect was not as strong as in WI-38 cells. This is most likely due to the fact that the IMR-90 cells go through $\sim 60$ PDs prior to senescence (Forsyth et al. 2003). In the case of WI-38 cells, these observations were extended to show that the slow proliferation following LB1 silencing was not attributable to a loss of cells by apoptosis, as determined by the TUNEL reaction (data not shown). In addition, after $12 \mathrm{~d}$, the number of LB1 silenced cells positive for SAHFs $(\sim 45 \%[n=432] \mathrm{LB} 1 \mathrm{sh} ; \sim 0.5 \%$ $[n=430]$ Sc), and SA- $\beta$-gal activity $(\sim 42 \%[n=434] \mathrm{LB} 1 \mathrm{sh}$; $\sim 4 \%[n=481]$ Sc) increased, and there was a large decrease in cells incorporating BrdU $(\sim 12 \%$ LB1sh $[n=$ 745]; $41 \%$ Sc $[n=697]$ ) (see Fig. $3 C$ ). In addition, LB1 could not be detected by microscopy in cells containing nuclei with SAHFs (Fig. 3D). These results demonstrate that LB1 silencing slows cell proliferation and induces premature senescence.

The roles of $p 53$ and $p R b$ in the inhibition of cell proliferation and the induction of premature senescence by LB1 silencing

In order to investigate the process of premature senescence induced by LB1 silencing, the human cellular senescence PCR array (SA-Biosciences, Qiagen) was used to analyze 84 genes involved in the initiation and progression of senescence. To identify mechanisms involved following LB1 silencing, this analysis was carried out $3 \mathrm{~d}$ following selection. This is the time at which recognizable changes in the proliferation rate of WI-38 cells were first observed (see Fig. 3B). The mRNA levels of 45 genes were significantly altered by over twofold; 43 genes were up-regulated and two genes were down-regulated. Among the 45 genes affected, 41 were altered as expected for cells undergoing senescence by known mechanisms (Supplemental Table S1; GeneCards, http://www.genecards.org).

The involvement of the p53 pathway in the LB1 silencing effects was examined using immunoblotting to measure p53 levels in whole-cell lysates prepared $6 \mathrm{~d}$ after selection. LB1 silencing caused an $\sim 39 \%$ increase in p53 compared with Sc (Fig. 4A). At 3 d following selection, the transcript levels of the p53 gene TP53 increased $\sim 7.5$ fold, and the transcript levels of the mediator of p53dependent senescence, p21(CDKN1A), increased approximately sixfold over control levels (Supplemental Table S1). The contribution of p53 to proliferation and senescence was investigated by expressing the p53 miniprotein p53DD and subsequently silencing LB1. p53DD inactivates p53 and prevents its degradation (Shaulian et al. 1992), as evidenced by increased levels of p53 in p53DDexpressing cells (Fig. 4B). When p53 was inactivated by p53DD expression, the proliferation rates of both LB1sh and Sc cells were increased (Fig. 4C), with no significant differences between the two detected within $12 \mathrm{~d}$ (Fig. 4C). In addition, no differences in the numbers of cells with SAHFs, staining for SA- $\beta$-gal, or incorporating BrdU were detected (data not shown). Similarly, in cells where p53 was down-regulated by shRNA, there was no significant 
difference in proliferation between Sc and LB1 silenced cells (Fig. $4 \mathrm{D}, \mathrm{E}$ ). Therefore, a functional p53 pathway is required for both the decreased proliferation rate and the induction of premature senescence caused by LB1 silencing.

The involvement of the $\mathrm{pRb}$ pathway in the effects of LB1 silencing was analyzed by immunoblotting of wholecell lysates prepared $6 \mathrm{~d}$ after selection. LB1 silencing caused a $71 \%$ decrease in nonphosphorylated $\mathrm{pRb}$ and a $75 \%$ decrease in phospho-pRb as compared with controls (Fig. 4F, left two lanes; DeCaprio et al. 1989). In addition, the level of $R B 1$ transcripts was decreased by approximately fivefold by $3 \mathrm{~d}$ following selection (Supplemental Table S1). The contribution of $\mathrm{pRb}$ to proliferation and senescence was investigated by expression of the HPV oncoprotein E7 to induce $\mathrm{pRb}$ degradation (Fig. 4F; Boyer et al. 1996). E7 was used in this experiment rather than E1A (see Fig. 2B), since it specifically inhibits the Rb family and does not sensitize the cells to apoptosis, as is the case with E1A (Deng et al. 2005). In our hands, attempts to silence LB1 in E1A-expressing cells led to increased apoptosis with both the LB1 silencing and control vectors (data not shown).When LB1 was silenced in E7-expressing cells, both silenced and Sc cells showed increased proliferation rates relative to non-E7-expressing cells (Fig. 4G). However, the proliferation rates of LB1 silenced cells were

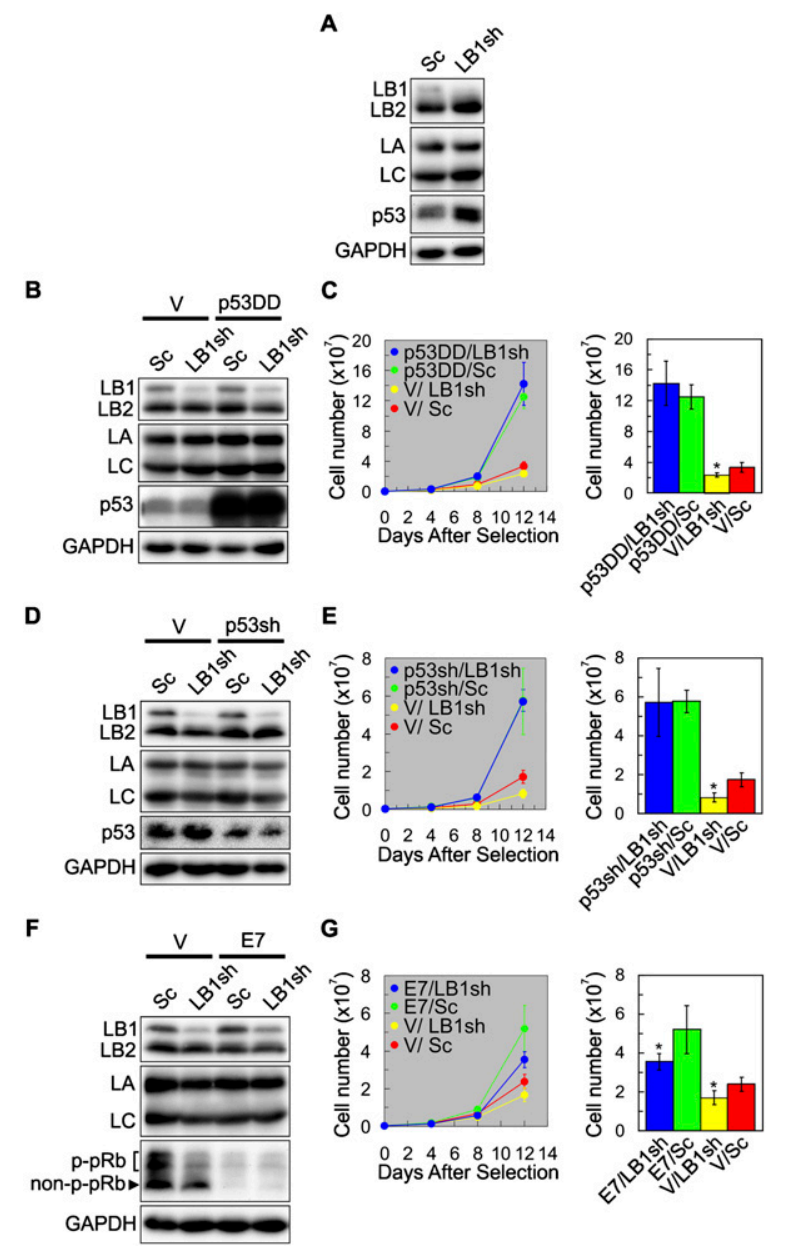

consistently slower than Sc cells whether or not $\mathrm{pRb}$ was inactivated (Fig. 4G). This slower proliferation was not attributable to apoptosis, as determined by the TUNEL reaction (data not shown). Additionally, E7-expressing cells did not become senescent, as evidenced by continuous proliferation and the lack of senescence marks (data not shown). These results demonstrate that the $\mathrm{pRb}$ pathway is not required for the decreased proliferation induced by LB1 silencing. However, $\mathrm{pRb}$ is required for LB1 silenced cells to become prematurely senescent.

\section{The decrease in cell proliferation accompanying LB1 silencing is independent of telomere dysfunction}

The requirement for activation of p53 for the slow proliferation and premature senescence induced by LB1 silencing suggests that LB1 has a role in the maintenance of cell proliferation upstream of the p53 pathway. One possible upstream process involving LB1 is telomere dysfunction. Although there is no known relationship between LB1 and telomeres, it has been shown that the A-type lamins are involved in the maintenance of telomeres (GonzalezSuarez et al. 2009) and that dysfunctional telomeres are associated with DNA damage foci as marked by $\gamma \mathrm{H} 2 \mathrm{AX}$

Figure 4. p53, but not $\mathrm{pRb}$, is required for the inhibition of cell proliferation by LB1 silencing. (A) WI-38 cells (PD24) were transfected with either the LB1sh or Sc vector. Six days after selection, the expression levels of LB1, LB2, LA/C, and p53 were determined by immunoblotting. $(B-G)$ The requirements of the p53 and pRb pathways for the LB1 silencing effects on cell proliferation were examined. (B) Cells were transfected with either a p53 deletion mutant (p53DD) or a control vector (V), and then transfected with either LB1sh or Sc. $(C)$ The graph shows that expression of $\mathrm{p} 53 \mathrm{DD}$ resulted in increased proliferation and that there was no significant difference between p53DD/Sc (green) and p53DD/LB1sh (blue) $\left(n=3 ; P=3.2 \times 10^{-1}\right)$, but there was a change in proliferation between cells expressing $\mathrm{V} /$ Sc (red) and V/LB1sh (yellow) $\left.\left(n=3 ;{ }^{\star}{ }^{*}\right] P=8.0 \times 10^{-3}\right) .(D)$ Cells were transfected with either a p53 shRNA vector (p53sh) or a control vector $(\mathrm{V})$ and then transfected with either LB1sh or Sc. (E) The graph shows that proliferation increased in cells with less p53 expression and that there was no significant difference in proliferation between $\mathrm{p} 53 \mathrm{sh} / \mathrm{LB} 1 \mathrm{sh}$ (blue) and p53sh/Sc (green) $\left(n=3 ; P=9.7 \times 10^{-1}\right)$, but there was a significant difference between $\mathrm{V} / \mathrm{LB} 1 \mathrm{sh}$ (yellow) and $\mathrm{V} / \mathrm{Sc}($ red $)\left(n=3 ;{ }^{*}{ }^{\star}\right] P=$ $\left.5.7 \times 10^{-4}\right)$. The error bars for p53sh/LB1sh and $\mathrm{p} 53 \mathrm{sh} / \mathrm{Sc}$ overlap. $(F)$ Cells were transfected with either a HPV E7 vector or a control vector $(\mathrm{V})$ and then transfected with either LB1sh or $\mathrm{Sc}$. Nonphosphorylated and phosphorylated $\mathrm{pRb}$ are indicated as non-p-pRb and p-pRb, respectively. $(G)$ The graph shows that the proliferation of $\mathrm{V} / \mathrm{LB} 1 \mathrm{sh}$ (yellow) decreased compared with V/Sc (red) controls $\left(n=3\right.$; [ $\left.\left.{ }^{\star}\right] P=7.9 \times 10^{-3}\right)$. The rates of cell proliferation increased in E7/LB1sh and E7/Sc cells compared with $\mathrm{V} / \mathrm{LB} 1 \mathrm{sh}$ and $\mathrm{V} / \mathrm{Sc}$ cells; there were even greater increases in the E7/Sc (green) compared with E7/LB1 sh (blue) $\left(n=3 ;{ }^{\star}\right] P=$ $1.6 \times 10^{-2}$ ). For clarity, the data from day 12 following selection are also displayed as histograms in $C, E$, and $G$. No significant changes in LB2 and LA/C protein levels were detected in any of the cells examined. GAPDH was used as a loading control. Error bars in graphs represent standard deviations. The bars with an asterisk mark experiments with significant changes $\left(\left[{ }^{\star}\right] P<5.0 \times 10^{-2}\right)$. 
(d'Adda di Fagagna et al. 2003). Therefore, the association between $\gamma \mathrm{H} 2 \mathrm{AX}$ foci and telomeres was examined by immunofluorescence 3 and $6 \mathrm{~d}$ after selection of LB1 silenced cells. The majority of LB1sh and Sc cells contained only one or two of the large $\gamma \mathrm{H} 2 \mathrm{AX}$ foci (Supplemental Fig. S2A) typically associated with sites of DNA damage (d'Adda di Fagagna et al. 2003). The association of telomeres with $\gamma \mathrm{H} 2 \mathrm{AX}$ foci was examined by fluorescence in situ hybridization combined with immunofluorescence (immuno-FISH). The results showed no colocalization between telomeres and $\gamma \mathrm{H} 2 \mathrm{AX}$ foci in LB1sh cells (Supplemental Fig. S2B). Furthermore, no significant changes in telomere length could be detected, as assayed by telomere restriction fragment analyses on DNA isolated from LB1 silenced and control cells at both 3 and 6 $\mathrm{d}$ following selection (Supplemental Fig. S2C). These results demonstrate that telomere dysfunctions are not major contributors to the premature senescence induced by LB1 silencing.

\section{LB1 silencing inhibits cell proliferation through a reactive oxygen species (ROS) signaling pathway}

Another upstream event that acts through the p53 pathway to induce premature senescence is the production of abnormally high levels of ROS (Finkel and Holbrook 2000). To determine whether increased ROS levels were a possible cause of the premature senescence in LB1 silenced cells, a mitochondrial matrix targeted redox-sensitive green fluorescent protein (roGFP) was expressed (Dooley et al. 2004). In order to minimize the normal accumulation of mitochondrial ROS as cells approach senescence (Hagen et al. 1997), the analyses were carried out $3 \mathrm{~d}$ after selection for LB1 silencing, at which time LB1sh cells showed no changes in senescence markers (data not shown). Mitochondrial ROS was determined by roGFP fluorescence using flow cytometry. Surprisingly, there was an $\sim 28 \%(n=6)$ decrease in ROS in LB1 silenced cells compared with controls (Fig. 5A). These results were confirmed using another ROS indicator, carboxy- $\mathrm{H}_{2} \mathrm{DCFDA}$ (Supplemental Fig. S3A). Since mitochondrial oxidative phosphorylation is a major source of ROS in nontransformed cells, the oxygen consumption rate (OCR) of LB1 silenced and control cells was measured (Weinberg et al. 2010). LB1 silenced cells exhibited an increased OCR (Fig. $5 \mathrm{~B}$ ), but no change in mitochondrial mass (Supplemental Fig. S3B), suggesting that the oxidative capacity of individual mitochondria was increased.

The decrease in ROS in LB1 silenced cells even as oxygen consumption was increased suggested that LB1 silencing may up-regulate genes involved in the antioxidant response. Since p53 is activated by LB1 silencing and regulates antioxidant genes (Sablina et al. 2005), the role of p53 in mediating the decrease in ROS in LB1 silenced cells was investigated. The results showed no reduction in ROS in LB1sh cells expressing p53DD (Fig. 5C), demonstrating that activation of p53 was required for the decrease in ROS. Other evidence supporting the activation of p53 after LB1 silencing was obtained by measuring the mRNA levels of p53 (TP53) and the p53 target gene p21 (CDKN1A)
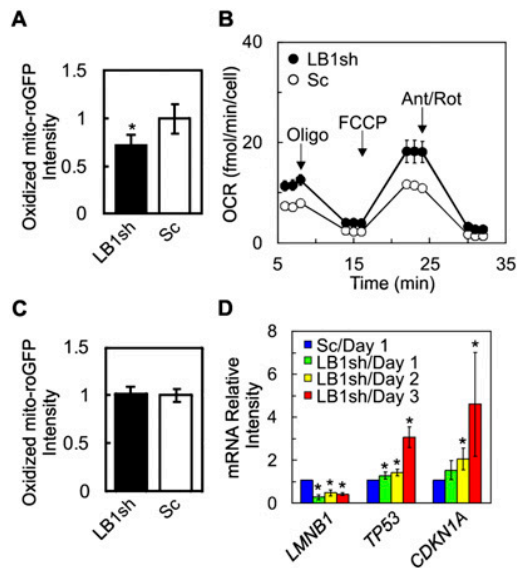

E

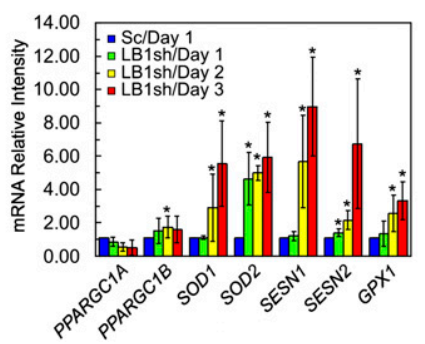

Figure 5. The effects of LB1 silencing on mitochondrial ROS. Expression of roGFP was examined in WI-38 cells $3 \mathrm{~d}$ after selection for cells expressing either LB1sh or Sc. (A) Flow cytometric analysis indicates that LB1sh reduces the amount of oxidized roGFP. The black and white bars indicate the normalized mean oxidation of roGFP in LB1sh and Sc cells, respectively $\left(n=6,\left[^{\star}\right] P=1.6 \times 10^{-2}\right)$. $(B)$ OCR was measured in LB1sh and Sc cells incubated in basal medium and subsequently exposed to oligomycin (oligo) for ATP inhibition, carbonyl cyanide p-trifluoromethoxy-phenylhydrazone (FCCP) for mitochondrial uncoupling, and antimycin A/rotenone (Ant/Rot) for inhibiting electron transfer in complex I and complex III /see the Materials and Methods). There was a significant difference between LB1sh and Sc cells $\left(\left[^{\star}\right] P=5.6 \times 10^{-4}, 3.4 \times 10^{-5}, 6.6 \times\right.$ $10^{-6}$ and $\left.2.2 \times 10^{-3}\right)$, respectively. The bars represent the standard errors of the mean. $(C)$ Expression of p53DD inhibits the decrease in roGFP in LB1sh cells. There was no significant difference in the amount of oxidized roGFP between LB1sh and Sc $\left(n=6 ; P=6.5 \times 10^{-1}\right)$. (D) The levels of transcripts (mRNAs) of the LB1 gene (LMNB1), the p53 gene (TP53), and the p21 gene (CDKN1A) were determined in LB1sh and Sc cells by qPCR every $24 \mathrm{~h}$ for $3 \mathrm{~d}$ after selection $\left(n=4 ;{ }^{\star}{ }^{\star}\right] P<5.0 \times 10^{-2}$ between Sc and LB1sh at days 1, 2, and 3). (E) The levels of transcripts (mRNAs) of the SOD1 (SOD1), SOD2 (SOD2), sestrin 1 (SESN1), sestrin 2 (SESN2), GPX1 (GPX1), PGC-1 $\alpha$ (PPARGC1A), and PGC-1 $\beta$ (PPARGC1B) genes in LB1sh and Sc cells were determined by qPCR every $24 \mathrm{~h}$ for $3 \mathrm{~d}$ after selection $\left(n=4{ }^{\left[{ }^{*}\right]} P<5.0 \times 10^{-2}\right.$ between Sc and LB1sh at days 1,2 , and 3). The error bars in $A, C, D$, and $E$ represent standard deviations. The bars with an asterisk mark experiments with significant changes $\left(\left[^{\star}\right] P<5.0 \times 10^{-2}\right)$.

by qRT-PCR every $24 \mathrm{~h}$, beginning immediately after selection. The mRNA levels of both genes gradually increased after LB1 silencing (Fig. 5D), indicating that the p53-p21 pathway was activated by LB1 silencing within $3 \mathrm{~d}$ after selection. In addition, the human cellular senes- 
cence PCR array data showed that other p53 target genes, such as PAI-1 (SERPINE1), were up-regulated (Supplemental Table S1). Furthermore, several p53 target genes involved in the antioxidant response-including superoxide dismutase1 (SOD1), SOD2, sestrin 1/PA26 (SESN1), sestrin 2/Hi95 (SESN2), and glutathione peroxidase 1 (GPX1) (Hussain et al. 2004; Sablina et al. 2005; Lebedeva et al. 2009; Spanier et al. 2009)-were also analyzed by qRTPCR during the first $3 \mathrm{~d}$ after selection. The transcript levels of each of these genes increased by approximately threefold to eightfold in LB1sh compared with Sc cells in a time-dependent fashion (Fig. 5E). Interestingly, transcription of SOD2 increased much earlier than the responses of the other antioxidant genes (Fig. 5E). In addition, two p53-regulated factors involved in regulating mitochondrial biogenesis-peroxisome proliferator-activated receptor $\gamma 1 \alpha($ PGC- $1 \alpha$; PPARGC1A) and PGC- $1 \beta$ (PPARGC1B)were examined (Sahin et al. 2011). No significant changes in transcription of these factors were detected, consistent with the observation that mitochondrial mass did not change in LB1sh cells (Fig. 5E; Supplemental Fig. S3). Taken together, these qRT-PCR analyses further demonstrate that LB1 silencing results in the reduction of mitochondrial ROS due to the activation of antioxidant genes regulated by p53.

The rapid decrease in ROS following the initiation of LB1 silencing suggested that increasing the levels of ROS might rescue the reduced proliferation caused by the loss of LB1. In support of this, several studies have shown that hypoxia $\left(1.5 \% \mathrm{O}_{2}\right)$ causes moderate increases in ROS and promotes the proliferation and longevity of HDFs in culture (Packer and Fuehr 1977; Bell et al. 2007). Therefore, we determined the proliferation rates of LB1 silenced and control cells under hypoxic conditions. The results showed that the rates of proliferation of LB1sh and Sc cells were indistinguishable (Fig. 6A, left and right), and both were faster than cells grown in normoxic $\left(21 \% \mathrm{O}_{2}\right)$ conditions (Fig. 6B, left). In order to demonstrate the specific contribution of ROS to the rate of proliferation in LB1sh cells under hypoxic conditions, a ROS scavenger, $\mathrm{N}$-acetyl-L-cysteine (NAC), was added to the cultures (Sekharam et al. 1998). Under these conditions, only the LB1sh cells showed decreased rates of proliferation (Fig. 6A, middle and right), suggesting that LB1sh cells are more sensitive than control cells to hypoxia-induced increases in ROS.

Both NAC-treated LB1sh and Sc cells grown under normoxic conditions exhibited slower proliferation rates than untreated cells (Fig. 6B, left and middle). Importantly, NAC treatment slowed proliferation of LB1sh cells to an even greater extent than the proliferation of nontreated LB1sh cells (Fig. 6B, right). Based on these observations, we also determined whether NAC treatment accelerated entry into senescence under normoxic conditions. At $8 \mathrm{~d}$ following selection, the number of cells positive for SA$\beta$-gal increased with NAC treatment $(\sim 15 \%[n=450]$ for LB1sh; $\sim 22 \%[n=432]$ for LB1sh with NAC; $\sim 3.4 \%[n=$ $500]$ for $\mathrm{Sc}_{;} \sim 7 \%$ [ $\left.n=430\right]$ for Sc with NAC) and SAHFs $(\sim 14 \%[n=594]$ for LB1sh; $\sim 21 \%[n=584]$ for LB1sh with $\mathrm{NAC} ; \sim 0.5 \%[n=769]$ for $\mathrm{Sc}_{;} \sim 5 \%[n=658]$ for Sc with
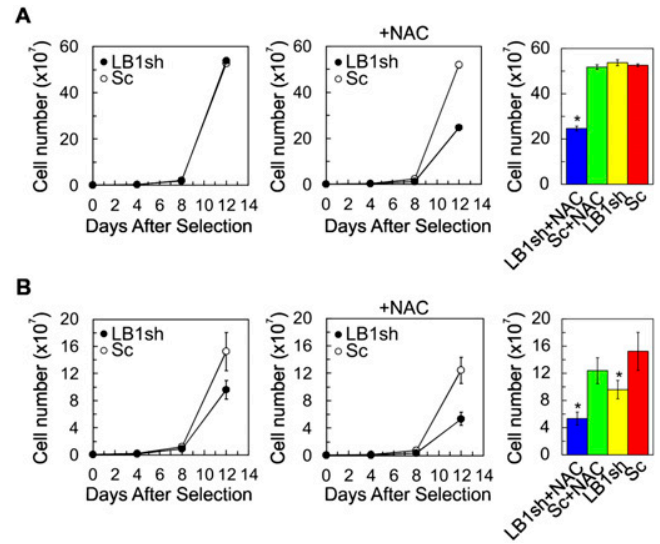

Figure 6. Hypoxia rescues the slow proliferation induced by LB1 silencing. (A) Proliferation of LB1sh and Sc cells under hypoxic conditions $\left(1.5 \% \mathrm{O}_{2}\right)$ in the presence or absence of NAC during selection and for $12 \mathrm{~d}$ after selection (see the Materials and Methods) $\left(n=3, P=8.5 \times 10^{-1}\right.$ for the difference between Sc and LB1sh; $\left.{ }^{\star}{ }^{\star}\right] P=3.2 \times 10^{-2}$ for the difference between $\mathrm{Sc} / \mathrm{NAC}$ and LB1sh/NAC). NAC treatment slowed proliferation in LB1sh (LB1sh/NAC) relative to nontreated LB1sh $\left(n=3\right.$; $\left.{ }^{*}\right]$ $\left.P=2.3 \times 10^{-3}\right) .(B)$ Proliferation of LB1sh and Sc cells grown under normoxic conditions $\left(21 \% \mathrm{O}_{2}\right)$ in the presence or absence of NAC during and for $12 \mathrm{~d}$ after selection (see the Materials and Methods) $\left(n=3,{ }^{*}{ }^{\star}\right] P=3.8 \times 10^{-3}$ for the difference between Sc [red] and LB1sh [yellow]; $\left.{ }^{\star}\right] P=1.3 \times 10^{-4}$ for the difference between Sc/NAC [green] and LB1sh/NAC [blue]). NAC treatment slowed proliferation in LB1sh (LB1sh/NAC) compared with nontreated LB1sh $\left.\left(n=3 ;{ }^{\star}\right] P=2.3 \times 10^{-3}\right)$. The histograms in $A$ and $B$ show the cell numbers at $12 \mathrm{~d}$ after selection. Error bars in graphs represent standard deviations. The bars with an asterisk mark experiments with significant changes $\left(\left[{ }^{*}\right] P<5.0 \times 10^{-2}\right)$.

NAC). There was also a decrease in cells incorporating $\operatorname{BrdU}(\sim 18 \%[n=707]$ for $\mathrm{LB} 1 \mathrm{sh} ; \sim 11 \%[n=906]$ for LB1sh with NAC; $\sim 39 \%[n=779]$ for Sc; $\sim 27 \%[n=738]$ for Sc with NAC). Taken together, the results of silencing LB1 expression under hypoxic or normoxic conditions suggest that a ROS signaling pathway is responsible for the effects of silencing on proliferation and induction of the senescence program.

Overexpression of LB1 increases the proliferation rate and arrests cells in the G1 phase of the cell cycle

Since LB1 silencing slowed the proliferation rate and induced the premature senescence of WI-38 cells, it seemed plausible that the overexpression of LB1 might affect the proliferation rate and the onset of senescence. To test these possibilities, GFP-LB1 was expressed in WI-38 cells at PD24 and cell proliferation was monitored. The expression levels of LA/C, LB1, and LB2 in cells expressing GFP-LB1 were analyzed by fluorescence microscopy and immunoblotting $14 \mathrm{~d}$ after selection (Fig. 7A,B). There were no significant changes in the expression of endogenous LA/C, LB1, and LB2 in either GFP-LB1-expressing cells or controls expressing only GFP (Fig. 7B). The amount of GFP-LB1 expressed was $\sim 10$-fold to 15 -fold greater than the level of endogenous LB1 (Fig. 7B). The two bands migrating near the predicted molecular weight of GFP-LB1 


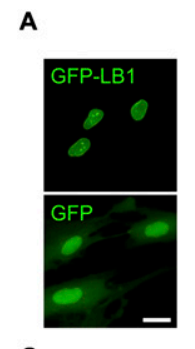

B

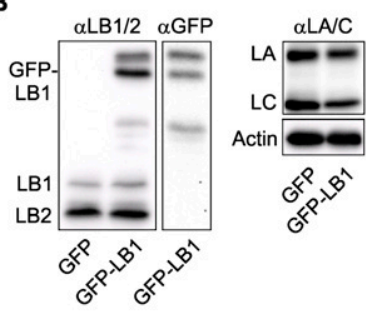

C

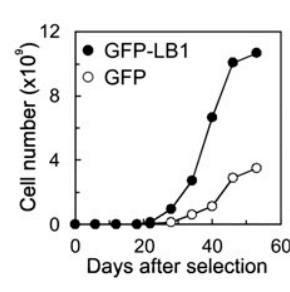

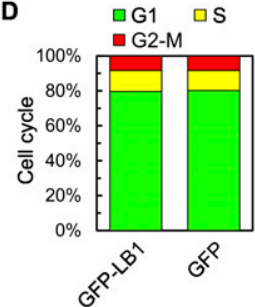

E

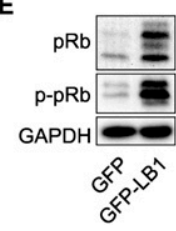

Figure 7. The effects of GFP-LB1 overexpression on cell proliferation. (A) Localization of GFP-LB1 and GFP (control) in WI38 cells. Bar, $20 \mu \mathrm{m} .(B)$ The expression levels of GFP-LB1 and endogenous LA/C, LB1, and LB2 were determined by immunoblotting of whole-cell lysates prepared $14 \mathrm{~d}$ following selection. Cells appeared to express multiple forms of LB1, including the top band, most likely representing the nonfarnesylated form of LB1 (see the Results), and the second band, representing the farnesylated form. (C) Increased proliferation in GFP-LB1expressing cells (closed circle) compared with GFP-expressing cells (open circle) (see Supplemental Fig. S4 for another set of proliferation curves). (D) Cell cycle analyses of the cells expressing GFP or GFP-LB1 by flow cytometry when they stopped proliferating. $(E)$ Expression and phosphorylation of $\mathrm{pRb}$ in cells expressing GFP and GFP-LB1. Phosphorylated $\mathrm{pRb}$ is indicated as p-pRb. GAPDH was used as a loading control.

probably represent the farnesylated and nonfarnesylated forms of the protein (Maske et al. 2003). This accumulation could be attributable to the overexpression of the nonfarnesylated form, which likely overwhelms the lamin processing enzymes (our unpublished observations). The lower-molecular-weight bands seen in the GFP-LB1expressing cells have been reported in HDFs expressing different types of GFP fusion proteins (Narita et al. 2006). These bands probably represent prematurely truncated or incompletely translated proteins due to overexpression. Importantly, the average proliferation rate of the GFP-LB1expressing cells was $\sim 1.4$ times faster than that of GFPexpressing control cells in the time period between 18 and $34 \mathrm{~d}$ after selection (see Fig. 7C; Supplemental Fig. S4; see the Materials and Methods). Flow cytometric analyses of the cells at the time they stopped proliferating (53 d after selection) showed that $\sim 80 \%$ of both the GFP-LB1-expressing cells and the controls were in G1, which is consistent with senescence (Fig. 7D; Campisi and d'Adda di Fagagna
2007). Since LB1 silenced cells exhibit reduced pRb phosphorylation (see Fig. 4D), the phosphorylation state of $\mathrm{pRb}$ was examined in the GFP-LB1-expressing cells at day 53. Surprisingly, there was a ninefold increase in both $\mathrm{pRb}$ and phospho-pRb in GFP-LB1-expressing cells compared with GFP-expressing cells (Fig. 7E). These results show that overexpression of LB1 increases the rate of proliferation and delays the onset of senescence of HDFs.

\section{Discussion}

Our results suggest that the nuclear intermediate filament protein LB1 plays an important role in the maintenance of cell proliferation. As further evidence for this role, LB1 levels decrease dramatically as cells become senescent, and when LB1 is depleted from cells, they become prematurely senescent. Although LA, LC, and LB2 do not appreciably decrease in their expression during senescence, mutations in $L M N A$ and alterations in the amount of wildtype LA and the unprocessed precursor of LA (pre-LA) have been shown to cause premature senescence (Huang et al. 2008; Kandert et al. 2009; Taimen et al. 2009; Ragnauth et al. 2010; Moiseeva et al. 2011). One of these LMNA mutations, which is the most prevalent mutation causing Hutchinson-Gilford progeria syndrome (HGPS), results in the accumulation of a permanently farnesylated form of LA with a 50-amino-acid deletion near the $\mathrm{C}$ terminus, called LA $\Delta 50 /$ progerin. Progerin has also been observed to accumulate in an age-dependent fashion in tissues of normal individuals and in late-passage normal cultured cells (Scaffidi and Misteli 2006; McClintock et al. 2007; Rodriguez et al. 2009; Cao et al. 2011). Pre-LA has also been reported to accumulate in senescent cells (Ukekawa et al. 2007). However, we did not detect the expression of either progerin or pre-LA in spontaneously senescent cells or LB1 silencing-induced prematurely senescent cells (see Figs. 1C, 3A).

LMNB1 is an E2F target gene (Hallstrom et al. 2008), and the reduction of its expression during senescence is mediated by $\mathrm{pRb}$. Silencing LB1 expression immediately slows proliferation and induces premature senescence in HDFs, similar to the effects of silencing other E2F target genes (Gjoerup et al. 2007; Ibarra et al. 2008). We also show that $L M N B 1$ expression is unaltered in quiescent cells, as it is in the subset of E2F1 target genes that do not respond to serum stimulation (Hallstrom et al. 2008). The induction of premature senescence by LB1 silencing requires both p53 and pRb, but only p53 is required for the inhibition of proliferation. Furthermore, LB1 silencing activates the p53 pathway, up-regulating the transcription of p53 target genes such as p21. These results suggest that LB1 is involved in some activity that, when disrupted, signals through p53. Our data also demonstrate that $\mathrm{pRb}$ levels decrease and the expression of $R B 1$ is repressed within $3 \mathrm{~d}$ after LB1 silencing. The depletion of $\mathrm{pRb}$ from cells by E7 expression prior to LB1 silencing has no effect on the inhibition of proliferation by silencing, suggesting that the proliferation defects are mediated primarily by p53 activation. Although E7 expression and LB1 silencing both decrease $\mathrm{pRb}$ levels, E7 expression increases proliferation 
rates, whereas LB1 silencing decreases proliferation rates. If LB1 is involved in a process required for proliferation, the loss of LB1 after silencing would prevent any increase in proliferation rates due to the silencing-induced loss of $\mathrm{pRb}$ control over cell cycle progression. We showed previously that B-type lamins are associated with sites of DNA replication during mid-late S (Moir et al. 1994), and disruption of lamin networks inhibits replication (Spann et al. 1997; Moir et al. 2000a). Therefore, DNA replication is one possible function that may be disrupted by LB1 silencing. The failure to correctly replicate DNA activates a DNA damage response, leading to activation of the p53 pathway, inhibition of proliferation, and induction of the senescence program. While we did not observe an increase in $\gamma-\mathrm{H} 2 \mathrm{AX}$ foci after silencing, there was an increase in the expression of ATM, CHEK1, and CHEK2, suggesting that silencing LB1 leads to defects in DNA replication (see Supplemental Table S1).

The reduction in ROS levels following selection for LB1 silencing is an intriguing clue to the mechanisms behind the inhibition of proliferation and induction of premature senescence. ROS levels steadily increase as cells progress through the cell cycle, and antioxidant treatment induces cell cycle arrest in late G1 (Havens et al. 2006). In addition, modest increases in ROS levels due to hypoxia or prooxidant treatment are known to increase the proliferation rates of normal cells in culture and whole organisms (Bell et al. 2007; Lee et al. 2010; Yang and Hekimi 2010). Taken together, these findings suggest that the decreased ROS levels detected shortly after silencing LB1 are insufficient to promote proliferation. This idea is supported by the rescue of the LB1 silencing proliferation defect under hypoxic conditions, which increases ROS, and by the increased sensitivity of LB1 silenced cells to NAC under normoxic conditions. The activation of several antioxidant genes within the first $3 \mathrm{~d}$ after silencing is a likely cause of this decrease in ROS. p53 plays a central role in regulating metabolism, most prominently in stimulating mitochondrial oxidative phosphorylation (Matoba et al. 2006). Many antioxidant genes are also regulated by p53; therefore, their up-regulation in our experiments is consistent with the observed activation of the p53 pathway (Sablina et al. 2005). Interestingly, the mitochondrial SOD2 gene is significantly up-regulated within $24 \mathrm{~h}$ after selection, prior to detectable activation of $\mathrm{p} 53$. This suggests that the up-regulation of $S O D 2$ may be independent of p53, although the up-regulation of SOD2 induced by LB1 silencing may also contribute to the activation of p53 (Behrend et al. 2005). The increased oxygen consumption and up-regulation of antioxidant genes in LB1 silenced cells may be due to a positive feedback mechanism initiated by LB1 silencing. Lamins have been implicated in transcriptional control (Spann et al. 2002) and bind directly to several transcription factors (Dechat et al. 2008). Therefore, it is possible that LB1 may more directly regulate the expression of SOD2 as well as other genes through interactions with transcription factors. Alternatively, LB1 may regulate chromatin organization and gene expression at a more global level (Guelen et al. 2008; Shimi et al. 2008). Consistent with previous studies demonstrating that senescent cells accumulate ROS (Hagen et al. 1997), our results show that ROS levels increase as LB1 silenced cells become senescent (data not shown). This later increase in ROS could be attributable to the activation of p21, since a feedback loop between p21 and ROS production is required for maintaining senescence (Macip et al. 2002; Passos et al. 2010).

A requirement for continued LB1 expression to maintain proliferation may not be universal. If the effects of LB1 loss are mediated by ROS, cell types may differ in their response to LB1 loss relative to how they respond to changes in ROS. The cell type differences may be related to the wide ranges of oxygen tensions to which cells are exposed, depending on their locations within the body. For example, keratinocytes produce more ROS than fibroblasts in response to stress (Varani et al. 2005), and therefore fibroblasts may exhibit more significant proliferation defects than keratinocytes after the reduction of ROS caused by LB1 silencing. This may explain why keratinocytes derived from $L M N B 1^{\Delta / \Delta} / L M N B 2^{\Delta / \Delta}$ mice do not show proliferation defects (Yang et al. 2011). It is important to note that one study found increased ROS levels in mouse fibroblasts following LB1 silencing (Malhas et al. 2009). The discrepancy with our results may be attributable to the differences in experimental design and the known differences in susceptibility to oxidative stress in human compared with mouse fibroblasts (Parrinello et al. 2003). Several studies have also highlighted differences in the senescence mechanisms between fibroblasts and mesothelial cells (Rheinwald et al. 2002). In addition, there may also be differences in the sensitivity to ROS between dermal fibroblasts and fetal lung fibroblast lines like the WI-38 and IMR-90 cells used in this study (Atamna et al. 2000; Wright and Shay 2001; Rheinwald et al. 2002).

Our results also demonstrate that overexpression of GFP-LB1 and silencing of LB1 have opposite effects on the rate of cell proliferation. The mechanisms responsible for regulating proliferation and senescence by overexpressing LB1 remain unknown. It is possible that the overexpression of LB1 could act as a competitive inhibitor for farnesyltransferase and affect the farnesylation state of other proteins, such as Ras, that are involved in regulating cell proliferation (Sebti 2005). However, we did not observe the accumulation of pre-LA or nonfarnesylated endogenous LB1 and LB2 when LB1 was overexpressed, suggesting that other farnesylated proteins were probably not affected (see Fig. 7B). Surprisingly, when GFP-LB1-overexpressing cells cease proliferating, we detected increased levels of both $\mathrm{pRb}$ and phosphorylated $\mathrm{pRb}$, indicating that their growth arrest is in late G1, most likely at the G1/S transition (Coller 2007). In contrast, when cells become spontaneously senescent or prematurely senescent by LB1 silencing, $\mathrm{pRb}$ levels decrease and the cells arrest in early G1 (Burkhart and Sage 2008). Together, these results imply that LB1 levels are important for regulating the entry of cells into $S$ phase. It is also possible that mechanisms such as the $\mathrm{pRb}$ pathway might be affected through the association of LB1 with LA/C by regulating functional interactions between LA/C and other factors (Shimi et al. 2008). Support for this idea comes from the findings that LA or 
LA-LAP2 $\alpha$ complexes bind to and stabilize $\mathrm{pRb}$ (Mancini et al. 1994; Nitta et al. 2006; Dorner et al. 2007; Pekovic et al. 2007), and the stabilization of pRb by LA is associated with cell cycle arrest (Johnson et al. 2004; Rodriguez et al. 2010). It is possible that the association of LB1 with LA/C affects the interactions of LA/C with other molecules, such as $\mathrm{pRb}$. The roles of LB1 in regulating cell proliferation and senescence may be linked to $\mathrm{pRb}$-mediated regulation of $L M N B 1$ expression through a feedback loop (Fig. 8). Although the precise mechanisms linking LB1 functions to ROS signaling are unknown, these findings have significant implications for our understanding of cell proliferation and senescence in normal development, aging, and cancer.

\section{Materials and Methods}

\section{Cell culture}

The human lung embryonic fibroblast lines WI-38 and IMR-90 (Coriell Cell Repositories) were cultured in modified Eagle's medium (MEM Alpha, Invitrogen) supplemented with 10\% fetal calf serum, $50 \mathrm{U} / \mathrm{mL}$ penicillin $\mathrm{G}$, and $50 \mu \mathrm{g} / \mathrm{mL}$ streptomycin sulfate (Invitrogen) at $37^{\circ} \mathrm{C}$ in a humidified $\mathrm{CO}_{2}$ incubator. For hypoxia experiments, cells were cultured in medium containing $20 \mathrm{mM}$ HEPES (Invitrogen) at $1.5 \% \mathrm{O}_{2}$ in an Invivo2 Hypoxia Workstation (Ruskinn Technology). To reduce ROS, cells were cultured in medium containing $1 \mathrm{mM} \mathrm{NAC} \mathrm{(Sigma-Aldrich)} \mathrm{and}$ $20 \mathrm{mM}$ HEPES both during and after selection. The medium was changed every $2 \mathrm{~d}$ with fresh medium supplemented with NAC.

\section{Proliferation assays}

For proliferation assays, cells were passaged at 3-7 d intervals, plating $2.5 \times 10^{5}$ cells per $10-\mathrm{cm}$ dish. At each passage, the cells from two 10-cm plates for each condition (control and experimental) were removed from the plates by trypsinization and counted using a hemocytometer. PDs were calculated using the equation $\mathrm{PD}=\log \left(\mathrm{N}_{\mathrm{h}} / \mathrm{N}_{\mathrm{s}}\right) / \log 2$, where $\mathrm{N}_{\mathrm{h}}=$ number of harvested cells and $\mathrm{N}_{\mathrm{s}}=$ number of seeded cells. Cumulative PDs were calculated by summing the PDs from all passages. Statistical analyses were performed using Gnumeric 1.10.16. The Student's $t$-test was used for most analyses. Differences in cell proliferation rates between samples were analyzed by two-factor ANOVA with

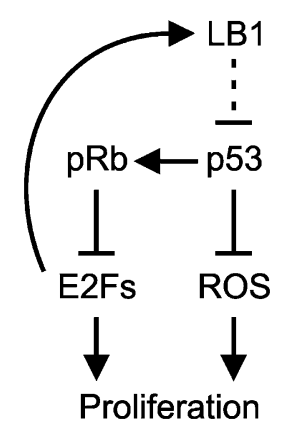

Figure 8. Summary of results for LB1 function in cell proliferation. As an E2F target gene, LMNB1 expression is regulated in response to the proliferation state of the cell. The data show that LB1 functions are upstream of p53. However, the exact mechanisms involved in the regulation of p53 by LB1 are not known (dashed line). replication. Proliferation rates (PRs) in exponential growth phase were calculated using the equation $\mathrm{PR}=\left(\mathrm{N}_{\mathrm{h}}-\mathrm{N}_{\text {reh }}\right) / \mathrm{N}_{\text {reh }}$, where $\mathrm{N}_{\text {reh }}=$ number of harvested cells at the previous time point.

\section{Retrovirus vectors}

For silencing the expression of LB1, we prepared the retrovirus vectors pSilencer-HsLMNB1shRNA-T3, pSilencer-HsLMNB1shRNA$\mathrm{T} 4$, and pSilencer-Scrambled (used as a control) according to the manufacturer's instructions (Ambion). pSilencer 5.1-H1 Retro precut with HindIII and BamHI was ligated with the target sequences for silencing LB1 (Shimi et al. 2008). For overexpressing GFP and GFP-LB1, the retrovirus vectors pQCXIP-GFP and pQCXIP-GFP-myc-Hs $L M N B 1$ were prepared using In-Fusion HD EcoDry cloning system (Clontech). The DNA fragments of GFP and GFP-myc-HsLMNB1 with BamHI was PCR-amplified using pEGFP-C1 (Clontech) and pEGFP-myc-HsLMNB1 (Moir et al. $2000 \mathrm{~b}$ ) and inserted into pQCXIP vector (Clontech). For induction of oncogenic stress, RasG12V was expressed from pBABE-puroRasG12V with pBABE-puro as a control (both provided by Dr. Scott Lowe, Cold Spring Harbor Laboratory through Addgene, http://www.addgene.org). $\mathrm{pRb}$ was inactivated by expression of HPV E7 from pLXSN-16E7 with pLXSN as a control (both provided by Dr. D. Galloway, Fred Hutchinson Cancer Research Center). In addition, for the inactivation of $\mathrm{pRb}$ followed by the introduction of RasG12V, the human adenovirus E1A protein was expressed from pWZL-hygro-12SE1A with pWZL-hygro as a control (both provided by Dr. Scott Lowe, Cold Spring Harbor Laboratory through Addgene). E1A was used in experiments to induce senescence with RasG12V, since inactivation of $\mathrm{pRb}$ by the expression of E7 is not sufficient to prevent cells from undergoing RasG12V-induced premature senescence (Deng et al. 2005). p53 was inactivated by expression of p53DD from pBABEhygro-p53DD with pBABE-hygro as a control (both provided by Dr. Robert Weinberg, Whitehead Institute for Biomedical Research through Addgene) or silenced using pMSCV-hygro-miR30 (p53 shRNA) with pMSCV-hygro as a control (both provided by Dr. Scott Lowe, Cold Spring Harbor Laboratory). For retrovirus production, $20 \mu \mathrm{g}$ of virus vector and $1 \mu \mathrm{g}$ of pVSV-G (Clontech) were electroporated into GP2-293 packaging cells (Clontech). Virus-containing culture supernatants were collected at 24, 36, and $48 \mathrm{~h}$ following transfection. For transduction of virus into cells, the culture supernatants containing virus were diluted sixfold in fresh medium containing $4 \mu \mathrm{g} / \mathrm{mL}$ polybrene (SigmaAldrich) and incubated with WI-38 cells (PD 24) for $12 \mathrm{~h}$. The culture medium was replaced with fresh virus-containing medium for an additional $12 \mathrm{~h}$ before replacement with medium containing antibiotics for selection. Virally transduced cells were selected by incubation in medium containing $3 \mu \mathrm{g} / \mathrm{mL}$ puromycin (Sigma-Aldrich), $200 \mu \mathrm{g} / \mathrm{mL}$ hygromycin B (Sigma-Aldrich), or $300 \mu \mathrm{g} / \mathrm{mL}$ G-418 (Clontech) for 3, 4, or $7 \mathrm{~d}$, respectively. Following selection, the cells were incubated in medium without antibiotics. When two retrovirus vectors containing different selection markers were used, the viral transduction procedures for each vector were carried out sequentially prior to selection. Cells selected with antibiotics were incubated in fresh medium without antibiotics for at least $12 \mathrm{~h}$ before any assays were performed.

\section{Measurement of ROS}

Mitochondrial ROS was determined by expressing roGFP fused to a mitochondrial localization sequence (Dooley et al. 2004; Hanson et al. 2004; Guzy et al. 2008). roGFP was introduced into the cells by adenovirus infection (5 PFU [plaque-forming units] per cell). After $24 \mathrm{~h}$, the infected cells were trypsinized and 
resuspended in PBS. The mean oxidation state of the roGFP was determined by measuring its fluorescence intensity with a Coulter CyAn (emission, $535 \mathrm{~nm}$; excitation, $405 \mathrm{~nm}$ and $488 \mathrm{~nm}$; Becton Dickinson). The fluorescence intensity was expressed as the ratio of oxidized $(405 \mathrm{~nm})$ to reduced $(488 \mathrm{~nm})$ roGFP. Maximum and minimum oxidation were determined after the cells were treated for $10 \mathrm{~min}$ with $1 \mathrm{mM}$ t-butyl hydroperoxide or $1 \mathrm{mM}$ dithiothreitol, respectively. Percent oxidation in the test sample was calculated by subtracting the minimum value from both the test sample and the maximum value and determining the ratio between those two values (Bell et al. 2007). Fold oxidation was calculated by normalizing the silenced samples to the controls. As an alternative method to measure ROS, total ROS was determined using Image-iT LIVE Green Reactive Oxygen Species Detection kit (Invitrogen) according to the manufacturer's instructions. Cells $\left(1.0 \times 10^{6}\right)$ grown in 10-cm culture dishes were incubated with Leibovitz's L-15 medium (Invitrogen) with $25 \mu \mathrm{M}$ 5-(and-6)-carboxy-2', $7^{\prime}$-dichlorodihydrofluorescein diacetate (carboxy- $\mathrm{H}_{2} \mathrm{DCFDA}$ ) for $30 \mathrm{~min}$ at $37^{\circ} \mathrm{C}$. Treated cells were trypsinized and resuspended in PBS. The oxidation product of carboxy$\mathrm{H}_{2}$ DCFDA was measured with a Coulter Epics XL-MCL (Becton Dickinson).

\section{Measurement of mitochondrial mass}

Mitochondrial mass was determined using MitoTrackerR Deep Red FM (Invitrogen) according to the manufacturer's instructions. Cells $\left(1.0 \times 10^{6}\right.$ cells $)$ in $10-\mathrm{cm}$ culture dishes were incubated with Leibovitz's L-15 medium (Invitrogen) with 100 nM MitoTracker Deep Red FM for $30 \mathrm{~min}$ at $37^{\circ} \mathrm{C}$. Treated cells were trypsinized and resuspended in PBS. The signal of MitoTrackerR Deep Red FM was measured with a Coulter Epics XL-MCL (Becton Dickinson).

\section{Measurement of OCR}

OCR was measured with a Seahorse Bioscience instrument (model XF24) as previously described (Weinberg et al. 2010). Cells $\left(5.0 \times 10^{4}\right)$ were seeded in the custom 24-well plate in growth medium for $24 \mathrm{~h}$ before assay. Prior to the assay the cells were equilibrated with bicarbonate-free DMEM (Invitrogen) for $1 \mathrm{~h}$ at $37^{\circ} \mathrm{C}$ in an incubator lacking $\mathrm{CO}_{2}$. In the assay, $5 \mu \mathrm{M}$ oligomycin (oligo) for ATP inhibition and $10 \mu \mathrm{M}$ carbonyl cyanide p-trifluoromethoxy-phenylhydrazone (FCCP) for mitochondrial uncoupling or $2 \mu \mathrm{M}$ antimycin $\mathrm{A} /$ rotenone (Ant/Rot) for inhibiting electron transfer in complex I and complex III were added to the basal medium. Five minutes after the addition of each reagent, the rates of change of dissolved $\mathrm{O}_{2}$ concentration immediately surrounding the cells were measured for $1 \mathrm{~min}$ three times.

\section{$q R T-P C R$}

Total RNA from WI-38 cells was harvested using Trizol (Applied Biosystems) and subjected to DNase I (Promega) treatment (3 U/ $\mu \mathrm{L}$ reaction mixture), followed by an additional precipitation with Trizol. An ND-1000 Spectrophotometer (NanoDrop Technologies) was used to assess the quality and concentration of the RNA preparations. RT-PCR reactions were carried out with the SuperScript VILO cDNA Synthesis kit (Invitrogen). For qRT-PCR reactions, we used the Qiagen QuantiFast Multiplex RT-PCR kit. The primers for LMNA, LMNB1, LMNB2, TP53, CDKN1A, SOD1, SOD2, SESN1, SESN2, PPARGC1A, PPARGC1B, and GAPDH (QuantiTect Primer Assays kits) were obtained from Qiagen. For analysis of GPX1, we used forward primer TTCCCGT GCAACCAGTTTG and reverse primer TTCACCTCGCACT TCTCGAA. The data were analyzed as described (Schefe et al.
2006). In addition, human cellular senescence PCR array analysis was performed according to the manufacturer's protocol (SABiosciences, Qiagen). Each experiment was repeated at least twice using parallel cultures and employing multiple technical repeats. The qRT-PCR analyses were carried out in an MJ Engine using Opticon 3 software. Real-time PCR $P$-values were determined by Student's $t$-test, comparing $\Delta \mathrm{CT}$ for the target genes with the average $\Delta C T$ for the reference genes (Yuan et al. 2006).

\section{Gel electrophoresis and immunoblotting}

Total WI-38 cell protein lysates were prepared by trypsinizing cells from 10-cm dishes, washing the cells in PBS, and solubilizing the cell pellet in SDS-PAGE sample buffer (2\% SDS, $62.5 \mathrm{mM}$ Tris- $\mathrm{HCl}$ at $\mathrm{pH} 6.8,10 \%$ glycerol) (Laemmli 1970). The protein concentration of each sample was determined using the BCA protein assay kit (Thermo Scientific). Prior to electrophoresis, 2 - $\beta$-mercaptoethanol was added to a final concentration of $2 \%$, and the proteins were separated by SDS-PAGE on $10 \%$ gels and transferred to nitrocellulose. Immunoblotting was carried out with the primary antibodies mouse anti-LA/C (1:2500; 5G4), mouse antiLB1/2 (1:2000; 2B2), mouse anti-p53 (1:200; DO-1, Santa Cruz Biotechnology), rabbit anti-phospho-Rb (1:1000; Ser780 and Ser807/811, Cell Signaling), mouse anti-actin (1:5000; AC-15, Accurate Chemical), and mouse anti-GAPDH (1:4000; FF26A/ F9, Biolegend, Inc.). Horseradish peroxidase-conjugated secondary antibodies ( $1 \mathrm{mg} / \mathrm{mL}$ KPL) were used at a dilution of 1:50,000, and the peroxidase activity was detected using the Super Signal PicoWest Chemiluminescence Detection kit (Thermo Scientific). Images were collected with a Kodak Image Station 440CF and quantified using Kodak Molecular Imaging software.

\section{Immunofluorescence}

Cells grown on glass coverslips were fixed in either methanol for $10 \mathrm{~min}$ at $-20^{\circ} \mathrm{C}$ or $3.7 \%$ formaldehyde in phosphate-buffered saline (PBS) for $10 \mathrm{~min}$ on ice, followed by extraction in $0.1 \%$ Triton X-100 in PBS for $10 \mathrm{~min}$ at $22^{\circ} \mathrm{C}$. Primary antibodies included mouse anti-LA/C (1:200; JoL2, Chemicon), rabbit antiLA/C (1:500; \#266), rabbit anti-LB1 (1:1000) (Moir et al. 1995), goat anti-LB1 (1:300; M-20, Santa Cruz Biotechnology), mouse anti-LB2 (1:200; LN43, Abcam), and rabbit anti-LB2 (1:1000; \#327) (Shimi et al. 2008). Secondary antibodies included goat antimouse IgG-Alexa Fluor 488, goat anti-mouse IgG-Alexa Fluor 568, and donkey anti-goat Alexa Fluor 568 (all used at 1:200; Invitrogen). DNA was stained with $1 \mu \mathrm{g} / \mathrm{mL}$ Hoechst 33258 (Invitrogen). Following processing, coverslips were mounted on slides in $20 \mathrm{mM}$ Tris- $\mathrm{Cl}$ (pH 9.0) with 50\% glycerol and containing $1 \%$ p-phenylenediamine (Sigma-Aldrich). Fixed cells were observed with either a Zeiss AxioImager Z1 or a Zeiss LSM 510 META (Carl Zeiss) microscope using oil immersion objective lenses (PlanApochromat, 63× and 100×, 1.40 NA; Carl Zeiss).

\section{Replication labeling}

Detection of DNA replication was carried out as described (Moir et al. 1994). Cells were labeled with $10 \mu \mathrm{M}$ BrdU (Sigma-Aldrich) in growth medium for $6 \mathrm{~h}$ at $37^{\circ} \mathrm{C}$. BrdU-labeled DNA was detected with mouse monoclonal anti-BrdU (1:500; BU-33, Sigma-Aldrich), followed by goat anti-mouse IgG-Alexa Fluor 488 (1:200; Invitrogen).

\section{Detection of $S A-\beta$-gal activity}

SA- $\beta$-gal was detected as described (Dimri et al. 1995). Cells grown on coverslips were fixed with $2.0 \%$ glutaraldehyde and $3.7 \%$ 
formaldehyde for $15 \mathrm{~min}$ at room temperature. Following two washes with PBS, cells were incubated for $4 \mathrm{~h}$ at $37^{\circ} \mathrm{C}$ in a solution containing 5-bromo-4-chloro-3-indolyl- $\beta$-D-galactopyranoside.

\section{Detection of apoptosis}

Apoptosis was detected using the In Situ Cell Death Detection kit, TMR red (Roche) according to the manufacturer's instructions. Cells grown on glass coverslips were fixed in $3.7 \%$ formaldehyde in PBS for $60 \mathrm{~min}$ at room temperature, followed by extraction in $0.1 \%$ Triton X-100 in PBS for $2 \mathrm{~min}$ on ice. Fragmented DNA was labeled by the TUNEL reaction for 60 $\min$ at $37^{\circ} \mathrm{C}$. The TUNEL reaction was terminated by washing in PBS, and the total DNA was stained with Hoechst 33258.

\section{Immuno-FISH}

Telomeres were localized in nuclei of cells grown on coverslips using the PNA FISH kit/Cy3 (Dako) according to the manufacturer's instructions. Following the in situ hybridization, the cells were processed for indirect immunofluorescence with mouse anti$\gamma \mathrm{H} 2 \mathrm{AX}$ antibody (Millipore) and Alexa Fluor 488 goat anti-mouse IgG (Molecular Probes). DNA was stained with Hoechst 33258.

\section{Measurement of telomere restriction fragments}

Telomere length was determined by terminal restriction fragment analysis. Total genomic DNA was isolated from WI-38 cells using the DNeasy Blood and Tissue kit (Qiagen) and digested with a HinfI/RsaI enzyme mix (20 U per sample; New England Biolabs) overnight at $37^{\circ} \mathrm{C}$. The digested DNA was resolved by electrophoresis through a $0.8 \%$ agarose gel at $5 \mathrm{~V} / \mathrm{cm}$ for $4 \mathrm{~h}$, then denatured, neutralized, and transferred using capillary transfer overnight to a nylon membrane (Amersham Hybond- $\mathrm{N}^{+}$). An 800base-pair (bp) T2AG3 telomere repeat probe was prepared from pSty11 (provided by Dr. Titia de Lange, Rockefeller University through Addgene) by excision, gel extraction, and end-labeling with digoxigenin d-UTP (Roche). The probe was hybridized to the transfer membrane under standard conditions and visualized using chemiluminescence with alkaline phosphatase. The mean telomere length was determined as previously described (Harley et al. 1990).

\section{Cell cycle analysis}

Cells $\left(1.0 \times 10^{6}\right)$ were collected and fixed for $2 \mathrm{~h}$ on ice in $70 \%$ ethanol. The cells were then incubated for $20 \mathrm{~min}$ at $37^{\circ} \mathrm{C}$ in PBS containing $50 \mu \mathrm{g} / \mathrm{mL}$ propidium iodide, $200 \mu \mathrm{g} / \mathrm{mL}$ RNase A, and $0.1 \%$ Triton- $X$, followed by resuspension in PBS. The DNA content of each cell was measured by cell sorting with a Coulter Epics XL-MCL (Becton Dickinson).

\section{Acknowledgments}

This work was supported by grants to R.D.G. from the National Cancer Institute, the Grus-Lipper Foundation, and the Progeria Research Foundation; a Career Award in the Biological Sciences from the Burroughs Wellcome Fund and New Scholar in Aging Award from the Ellison Medical Foundation to S.T.K.; and 5R01CA123067-05 awarded to N.S.C.

\section{References}

Aebi U, Cohn J, Buhle L, Gerace L. 1986. The nuclear lamina is a meshwork of intermediate-type filaments. Nature 323: $560-564$.
Atamna H, Paler-Martinez A, Ames BN. 2000. N-t-butyl hydroxylamine, a hydrolysis product of $\alpha$-phenyl- $\mathrm{N}$-t-butyl nitrone, is more potent in delaying senescence in human lung fibroblasts. J Biol Chem 275: 6741-6748.

Behrend L, Mohr A, Dick T, Zwacka RM. 2005. Manganese superoxide dismutase induces p53-dependent senescence in colorectal cancer cells. Mol Cell Biol 25: 7758-7769.

Bell EL, Klimova TA, Eisenbart J, Schumacker PT, Chandel NS. 2007. Mitochondrial reactive oxygen species trigger hypoxiainducible factor-dependent extension of the replicative life span during hypoxia. Mol Cell Biol 27: 5737-5745.

Boyer SN, Wazer DE, Band V. 1996. E7 protein of human papilloma virus-16 induces degradation of retinoblastoma protein through the ubiquitin-proteasome pathway. Cancer Res 56: 4620-4624.

Burkhart DL, Sage J. 2008. Cellular mechanisms of tumour suppression by the retinoblastoma gene. Nat Rev Cancer 8: 671-682.

Campisi J, d'Adda di Fagagna F. 2007. Cellular senescence: When bad things happen to good cells. Nat Rev Mol Cell Biol 8: 729-740.

Cao K, Blair CD, Faddah DA, Kieckhaefer JE, Olive M, Erdos MR, Nabel EG, Collins FS. 2011. Progerin and telomere dysfunction collaborate to trigger cellular senescence in normal human fibroblasts. J Clin Invest 121: 2833-2844.

Coffinier C, Chang SY, Nobumori C, Tu Y, Farber EA, Toth JI, Fong LG, Young SG. 2010. Abnormal development of the cerebral cortex and cerebellum in the setting of lamin B2 deficiency. Proc Natl Acad Sci 107: 5076-5081.

Coffinier C, Jung HI, Nobumori C, Chang S, Tu Y, Barnes RH II, Yoshinaga Y, de Jong PJ, Vergnes L, Reue K, et al. 2011. Deficiencies in lamin B1 and lamin B2 cause neurodevelopmental defects and distinct nuclear shape abnormalities in neurons. Mol Biol Cell doi: 10.1091/mbc.E11-06-0504.

Coller HA. 2007. What's taking so long? S-phase entry from quiescence versus proliferation. Nat Rev Mol Cell Biol 8: 667-670.

d'Adda di Fagagna F, Reaper PM, Clay-Farrace L, Fiegler H, Carr P, Von Zglinicki T, Saretzki G, Carter NP, Jackson SP. 2003. A DNA damage checkpoint response in telomere-initiated senescence. Nature 426: 194-198.

DeCaprio JA, Ludlow JW, Lynch D, Furukawa Y, Griffin J, Piwnica-Worms H, Huang CM, Livingston DM. 1989. The product of the retinoblastoma susceptibility gene has properties of a cell cycle regulatory element. Cell 58: 1085-1095.

Dechat T, Pfleghaar K, Sengupta K, Shimi T, Shumaker DK, Solimando L, Goldman RD. 2008. Nuclear lamins: Major factors in the structural organization and function of the nucleus and chromatin. Genes Dev 22: 832-853.

Deng Q, Li Y, Tedesco D, Liao R, Fuhrmann G, Sun P. 2005. The ability of E1A to rescue ras-induced premature senescence and confer transformation relies on inactivation of both p300/CBP and Rb family proteins. Cancer Res 65: 82988307.

Dimri GP, Lee X, Basile G, Acosta M, Scott G, Roskelley C, Medrano EE, Linskens M, Rubelj I, Pereira-Smith O, et al. 1995. A biomarker that identifies senescent human cells in culture and in aging skin in vivo. Proc Natl Acad Sci 92: 9363-9367.

Dooley CT, Dore TM, Hanson GT, Jackson WC, Remington SJ, Tsien RY. 2004. Imaging dynamic redox changes in mammalian cells with green fluorescent protein indicators. J Biol Chem 279: 22284-22293.

Dorner D, Gotzmann J, Foisner R. 2007. Nucleoplasmic lamins and their interaction partners, $\mathrm{LAP} 2 \alpha, \mathrm{Rb}$, and BAF, in transcriptional regulation. FEBS J 274: 1362-1373. 
Finkel T, Holbrook NJ. 2000. Oxidants, oxidative stress and the biology of ageing. Nature 408: 239-247.

Forsyth NR, Evans AP, Shay JW, Wright WE. 2003. Developmental differences in the immortalization of lung fibroblasts by telomerase. Aging Cell 2: 235-243.

Gjoerup OV, Wu J, Chandler-Militello D, Williams GL, Zhao J, Schaffhausen B, Jat PS, Roberts TM. 2007. Surveillance mechanism linking Bub1 loss to the p53 pathway. Proc Natl Acad Sci 104: 8334-8339.

Goldman RD, Shumaker DK, Erdos MR, Eriksson M, Goldman AE, Gordon LB, Gruenbaum Y, Khuon S, Mendez M, Varga $\mathrm{R}$, et al. 2004. Accumulation of mutant lamin A causes progressive changes in nuclear architecture in HutchinsonGilford progeria syndrome. Proc Natl Acad Sci 101: 89638968.

Gonzalez-Suarez I, Redwood AB, Perkins SM, Vermolen B, Lichtensztejin D, Grotsky DA, Morgado-Palacin L, Gapud EJ, Sleckman BP, Sullivan T, et al. 2009. Novel roles for A-type lamins in telomere biology and the DNA damage response pathway. EMBO I 28: 2414-2427.

Guelen L, Pagie L, Brasset E, Meuleman W, Faza MB, Talhout W, Eussen BH, de Klein A, Wessels L, de Laat W, et al. 2008. Domain organization of human chromosomes revealed by mapping of nuclear lamina interactions. Nature 453: 948951.

Guzy RD, Sharma B, Bell E, Chandel NS, Schumacker PT. 2008. Loss of the SdhB, but Not the SdhA, subunit of complex II triggers reactive oxygen species-dependent hypoxia-inducible factor activation and tumorigenesis. Mol Cell Biol 28: $718-731$.

Hagen TM, Yowe DL, Bartholomew JC, Wehr CM, Do KL, Park JY, Ames BN. 1997. Mitochondrial decay in hepatocytes from old rats: Membrane potential declines, heterogeneity and oxidants increase. Proc Natl Acad Sci 94: 3064-3069.

Hallstrom TC, Mori S, Nevins JR. 2008. An E2F1-dependent gene expression program that determines the balance between proliferation and cell death. Cancer Cell 13: 11-22.

Hanson GT, Aggeler R, Oglesbee D, Cannon M, Capaldi RA, Tsien RY, Remington SJ. 2004. Investigating mitochondrial redox potential with redox-sensitive green fluorescent protein indicators. J Biol Chem 279: 13044-13053.

Harley CB, Futcher AB, Greider CW. 1990. Telomeres shorten during ageing of human fibroblasts. Nature 345: 458-460.

Havens CG, Ho A, Yoshioka N, Dowdy SF. 2006. Regulation of late G1/S phase transition and APC Cdh1 by reactive oxygen species. Mol Cell Biol 26: 4701-4711.

Huang S, Risques RA, Martin GM, Rabinovitch PS, Oshima J. 2008. Accelerated telomere shortening and replicative senescence in human fibroblasts overexpressing mutant and wild-type lamin A. Exp Cell Res 314: 82-91.

Hussain SP, Amstad P, He P, Robles A, Lupold S, Kaneko I, Ichimiya M, Sengupta S, Mechanic L, Okamura S, et al. 2004. p53-induced up-regulation of MnSOD and GPx but not catalase increases oxidative stress and apoptosis. Cancer Res 64: 2350-2356.

Ibarra A, Schwob E, Mendez J. 2008. Excess MCM proteins protect human cells from replicative stress by licensing backup origins of replication. Proc Natl Acad Sci 105: 8956-8961.

Johnson BR, Nitta RT, Frock RL, Mounkes L, Barbie DA, Stewart CL, Harlow E, Kennedy BK. 2004. A-type lamins regulate retinoblastoma protein function by promoting subnuclear localization and preventing proteasomal degradation. Proc Natl Acad Sci 101: 9677-9682.

Jones NC. 1990. Transformation by the human adenoviruses. Semin Cancer Biol 1: 425-435.
Kandert S, Luke Y, Kleinhenz T, Neumann S, Lu W, Jaeger VM, Munck M, Wehnert M, Muller CR, Zhou Z, et al. 2007. Nesprin-2 giant safeguards nuclear envelope architecture in LMNA S143F progeria cells. Hum Mol Genet 16: 2944-2959.

Kandert S, Wehnert M, Muller CR, Buendia B, Dabauvalle MC. 2009. Impaired nuclear functions lead to increased senescence and inefficient differentiation in human myoblasts with a dominant p.R545C mutation in the LMNA gene. Eur $I$ Cell Biol 88: 593-608.

Kapinos LE, Schumacher J, Mucke N, Machaidze G, Burkhard P, Aebi U, Strelkov SV, Herrmann H. 2010. Characterization of the head-to-tail overlap complexes formed by human lamin A, $\mathrm{B} 1$ and B2 'half-minilamin' dimers. J Mol Biol 396: 719-731.

Kennedy BK, Barbie DA, Classon M, Dyson N, Harlow E. 2000. Nuclear organization of DNA replication in primary mammalian cells. Genes Dev 14: 2855-2868.

Kosak ST, Skok JA, Medina KL, Riblet R, Le Beau MM, Fisher AG, Singh H. 2002. Subnuclear compartmentalization of immunoglobulin loci during lymphocyte development. Science 296: $158-162$.

Kumaran RI, Spector DL. 2008. A genetic locus targeted to the nuclear periphery in living cells maintains its transcriptional competence. J Cell Biol 180: 51-65.

Laemmli UK. 1970. Cleavage of structural proteins during the assembly of the head of bacteriophage T4. Nature 227: 680685.

Lebedeva MA, Eaton JS, Shadel GS. 2009. Loss of p53 causes mitochondrial DNA depletion and altered mitochondrial reactive oxygen species homeostasis. Biochim Biophys Acta 1787: 328-334.

Lee SJ, Hwang $A B$, Kenyon C. 2010. Inhibition of respiration extends $C$. elegans life span via reactive oxygen species that increase HIF-1 activity. Curr Biol 20: 2131-2136.

Liu GH, Barkho BZ, Ruiz S, Diep D, Qu J, Yang SL, Panopoulos AD, Suzuki K, Kurian L, Walsh C, et al. 2011. Recapitulation of premature ageing with iPSCs from Hutchinson-Gilford progeria syndrome. Nature 472: 221-225.

Macip S, Igarashi M, Fang L, Chen A, Pan ZQ, Lee SW, Aaronson SA. 2002. Inhibition of p21-mediated ROS accumulation can rescue p21-induced senescence. EMBO J 21: 2180-2188.

Malhas AN, Lee CF, Vaux DJ. 2009. Lamin B1 controls oxidative stress responses via Oct-1. J Cell Biol 184: 45-55.

Mancini MA, Shan B, Nickerson JA, Penman S, Lee WH. 1994. The retinoblastoma gene product is a cell cycle-dependent, nuclear matrix-associated protein. Proc Natl Acad Sci 91: 418-422.

Maske CP, Hollinshead MS, Higbee NC, Bergo MO, Young SG, Vaux DJ. 2003. A carboxyl-terminal interaction of lamin B1 is dependent on the CAAX endoprotease Rcel and carboxymethylation. I Cell Biol 162: 1223-1232.

Matoba S, Kang JG, Patino WD, Wragg A, Boehm M, Gavrilova O, Hurley PJ, Bunz F, Hwang PM. 2006. p53 regulates mitochondrial respiration. Science 312: 1650-1653.

McClintock D, Gordon LB, Djabali K. 2006. Hutchinson-Gilford progeria mutant lamin A primarily targets human vascular cells as detected by an anti-Lamin A G608G antibody. Proc Natl Acad Sci 103: 2154-2159.

McClintock D, Ratner D, Lokuge M, Owens DM, Gordon LB, Collins FS, Djabali K. 2007. The mutant form of lamin A that causes Hutchinson-Gilford progeria is a biomarker of cellular aging in human skin. PLOS ONE 2: e1269. doi: 10.1371/ journal.pone.0001269.

Meaburn KJ, Cabuy E, Bonne G, Levy N, Morris GE, Novelli G, Kill IR, Bridger JM. 2007. Primary laminopathy fibroblasts display altered genome organization and apoptosis. Aging Cell 6: 139-153. 
Moir RD, Montag-Lowy M, Goldman RD. 1994. Dynamic properties of nuclear lamins: Lamin B is associated with sites of DNA replication. J Cell Biol 125: 1201-1212.

Moir RD, Spann TP, Goldman RD. 1995. The dynamic properties and possible functions of nuclear lamins. Int Rev Cytol 162B: $141-182$.

Moir RD, Spann TP, Herrmann H, Goldman RD. 2000a. Disruption of nuclear lamin organization blocks the elongation phase of DNA replication. J Cell Biol 149: 1179-1192.

Moir RD, Yoon M, Khuon S, Goldman RD. 2000b. Nuclear Lamins A and B1. Different pathways of assembly during nuclear envelope formation in living cells. I Cell Biol 151: $1155-1168$.

Moiseeva O, Bourdeau V, Vernier M, Dabauvalle MC, Ferbeyre G. 2011. Retinoblastoma-independent regulation of cell proliferation and senescence by the p53-p21 axis in lamin A/Cdepleted cells. Aging Cell 10: 789-797.

Mounkes L, Kozlov S, Burke B, Stewart CL. 2003. The laminopathies: Nuclear structure meets disease. Curr Opin Genet Dev 13: 223-230.

Narita M, Nunez S, Heard E, Lin AW, Hearn SA, Spector DL, Hannon GJ, Lowe SW. 2003. Rb-mediated heterochromatin formation and silencing of E2F target genes during cellular senescence. Cell 113: 703-716.

Narita M, Krizhanovsky V, Nunez S, Chicas A, Hearn SA, Myers MP, Lowe SW. 2006. A novel role for high-mobility group a proteins in cellular senescence and heterochromatin formation. Cell 126: 503-514.

Nitta RT, Jameson SA, Kudlow BA, Conlan LA, Kennedy BK. 2006. Stabilization of the retinoblastoma protein by A-type nuclear lamins is required for INK4A-mediated cell cycle arrest. Mol Cell Biol 26: 5360-5372.

Packer L, Fuehr K. 1977. Low oxygen concentration extends the lifespan of cultured human diploid cells. Nature 267: 423-425.

Parrinello S, Samper E, Krtolica A, Goldstein I, Melov S, Campisi J. 2003. Oxygen sensitivity severely limits the replicative lifespan of murine fibroblasts. Nat Cell Biol 5: 741-747.

Passos JF, Nelson G, Wang C, Richter T, Simillion C, Proctor CJ, Miwa S, Olijslagers S, Hallinan J, Wipat A, et al. 2010. Feedback between p21 and reactive oxygen production is necessary for cell senescence. Mol Syst Biol 6: 347. doi: 10.1038/msb.2010.5.

Pekovic V, Harborth J, Broers JL, Ramaekers FC, van Engelen B, Lammens $M$, von Zglinicki $T$, Foisner $R$, Hutchison $C$, Markiewicz E. 2007. Nucleoplasmic LAP2 $\alpha$-lamin A complexes are required to maintain a proliferative state in human fibroblasts. J Cell Biol 176: 163-172.

Polager S, Ginsberg D. 2009. p53 and E2f: Partners in life and death. Nat Rev Cancer 9: 738-748.

Ragnauth CD, Warren DT, Liu Y, McNair R, Tajsic T, Figg N, Shroff R, Skepper J, Shanahan CM. 2010. Prelamin A acts to accelerate smooth muscle cell senescence and is a novel biomarker of human vascular aging. Circulation 121: 2200-2210.

Rheinwald JG, Hahn WC, Ramsey MR, Wu JY, Guo Z, Tsao H, De Luca M, Catricala C, O'Toole KM. 2002. A two-stage, p16(INK4A)- and p53-dependent keratinocyte senescence mechanism that limits replicative potential independent of telomere status. Mol Cell Biol 22: 5157-5172.

Rodier F, Munoz DP, Teachenor R, Chu V, Le O, Bhaumik D, Coppe JP, Campeau E, Beausejour CM, Kim SH, et al. 2011. DNA-SCARS: Distinct nuclear structures that sustain damage-induced senescence growth arrest and inflammatory cytokine secretion. J Cell Sci 124: 68-81.

Rodriguez S, Coppede F, Sagelius H, Eriksson M. 2009. Increased expression of the Hutchinson-Gilford progeria syndrome truncated lamin A transcript during cell aging. Eur J Hum Genet 17: 928-937.

Rodriguez J, Calvo F, Gonzalez JM, Casar B, Andres V, Crespo P. 2010. ERK1/2 MAP kinases promote cell cycle entry by rapid, kinase-independent disruption of retinoblastoma-lamin A complexes. J Cell Biol 191: 967-979.

Sablina AA, Budanov AV, Ilyinskaya GV, Agapova LS, Kravchenko JE, Chumakov PM. 2005. The antioxidant function of the p53 tumor suppressor. Nat Med 11: 1306-1313.

Sahin E, Colla S, Liesa M, Moslehi J, Muller FL, Guo M, Cooper M, Kotton D, Fabian AJ, Walkey C, et al. 2011. Telomere dysfunction induces metabolic and mitochondrial compromise. Nature 470: 359-365.

Scaffidi P, Misteli T. 2005. Reversal of the cellular phenotype in the premature aging disease Hutchinson-Gilford progeria syndrome. Nat Med 11: 440-445.

Scaffidi P, Misteli T. 2006. Lamin A-dependent nuclear defects in human aging. Science 312: 1059-1063.

Schefe JH, Lehmann KE, Buschmann IR, Unger T, Funke-Kaiser H. 2006. Quantitative real-time RT-PCR data analysis: Current concepts and the novel "gene expression's CT difference" formula. J Mol Med 84: 901-910.

Schermelleh L, Carlton PM, Haase S, Shao L, Winoto L, Kner P, Burke B, Cardoso MC, Agard DA, Gustafsson MG, et al. 2008. Subdiffraction multicolor imaging of the nuclear periphery with $3 \mathrm{D}$ structured illumination microscopy. Science 320: 1332-1336.

Sebti SM. 2005. Protein farnesylation: Implications for normal physiology, malignant transformation, and cancer therapy. Cancer Cell 7: 297-300.

Sekharam M, Trotti A, Cunnick JM, Wu J. 1998. Suppression of fibroblast cell cycle progression in G1 phase by N-acetylcysteine. Toxicol Appl Pharmacol 149: 210-216.

Serrano M, Lin AW, McCurrach ME, Beach D, Lowe SW. 1997. Oncogenic ras provokes premature cell senescence associated with accumulation of p53 and p16INK4a. Cell 88: 593-602.

Shaulian E, Zauberman A, Ginsberg D, Oren M. 1992. Identification of a minimal transforming domain of p53: Negative dominance through abrogation of sequence-specific DNA binding. Mol Cell Biol 12: 5581-5592.

Shimi T, Pfleghaar K, Kojima S, Pack C, Solovei I, Goldman AE, Adam SA, Shumaker DK, Kinjo M, Cremer T, et al. 2008. The A- and B-type nuclear lamin networks: Microdomains involved in chromatin organization and transcription. Genes Dev 22: 3409-3421.

Shumaker DK, Solimando L, Sengupta K, Shimi T, Adam SA, Grunwald A, Strelkov SV, Aebi U, Cardoso MC, Goldman RD. 2008. The highly conserved nuclear lamin Ig-fold binds to PCNA: Its role in DNA replication. J Cell Biol 181: 269-280.

Spanier G, Xu H, Xia N, Tobias S, Deng S, Wojnowski L, Forstermann U, Li H. 2009. Resveratrol reduces endothelial oxidative stress by modulating the gene expression of superoxide dismutase 1 (SOD1), glutathione peroxidase 1 (GPx1) and NADPH oxidase subunit (Nox4). I Physiol Pharmacol 60: $111-116$.

Spann TP, Moir RD, Goldman AE, Stick R, Goldman RD. 1997. Disruption of nuclear lamin organization alters the distribution of replication factors and inhibits DNA synthesis. J Cell Biol 136: 1201-1212.

Spann TP, Goldman AE, Wang C, Huang S, Goldman RD. 2002. Alteration of nuclear lamin organization inhibits RNA polymerase II- dependent transcription. J Cell Biol 156: 603-608.

Sullivan T, Escalante-Alcalde D, Bhatt H, Anver M, Bhat N, Nagashima K, Stewart CL, Burke B. 1999. Loss of A-type lamin expression compromises nuclear envelope integrity leading to muscular dystrophy. J Cell Biol 147: 913-920. 
Taimen P, Pfleghaar K, Shimi T, Moller D, Ben-Harush K, Erdos MR, Adam SA, Herrmann H, Medalia O, Collins FS, et al. 2009. A progeria mutation reveals functions for lamin A in nuclear assembly, architecture, and chromosome organization. Proc Natl Acad Sci 106: 20788-20793.

Ukekawa R, Miki K, Fujii M, Hirano H, Ayusawa D. 2007. Accumulation of multiple forms of lamin A with downregulation of FACE-1 suppresses growth in senescent human cells. Genes Cells 12: 397-406.

Varani J, Bhagavathula N, Nerusu KC, Sherzer H, Fay K, Boitano AE, Glick GD, Johnson K, Kang S, Opipari AW Jr. 2005. A novel benzodiazepine selectively inhibits keratinocyte proliferation and reduces retinoid-induced epidermal hyperplasia in organ-cultured human skin. J Pharmacol Exp Ther 313: 56-63.

Vergnes L, Peterfy M, Bergo MO, Young SG, Reue K. 2004. Lamin B1 is required for mouse development and nuclear integrity. Proc Natl Acad Sci 101: 10428-10433.

Weinberg F, Hamanaka R, Wheaton WW, Weinberg S, Joseph J, Lopez M, Kalyanaraman B, Mutlu GM, Budinger GR, Chandel NS. 2010. Mitochondrial metabolism and ROS generation are essential for Kras-mediated tumorigenicity. Proc Natl Acad Sci 107: 8788-8793.

Wright WE, Shay JW. 2001. Cellular senescence as a tumorprotection mechanism: The essential role of counting. Curr Opin Genet Dev 11: 98-103.

Yang W, Hekimi S. 2010. A mitochondrial superoxide signal triggers increased longevity in Caenorhabditis elegans. PLoS Biol 8: e1000556. doi: 10.1371/journal.pbio.1000556.

Yang SH, Chang SY, Yin L, Tu Y, Hu Y, Yoshinaga Y, de Jong PJ, Fong LG, Young SG. 2011. An absence of both lamin B1 and lamin B2 in keratinocytes has no effect on cell proliferation or the development of skin and hair. Hum Mol Genet 20: 3537-3544.

Yuan JS, Reed A, Chen F, Stewart CN Jr. 2006. Statistical analysis of real-time PCR data. BMC Bioinformatics 7: 85. doi: 10.1186/1471-2105-7-85. 


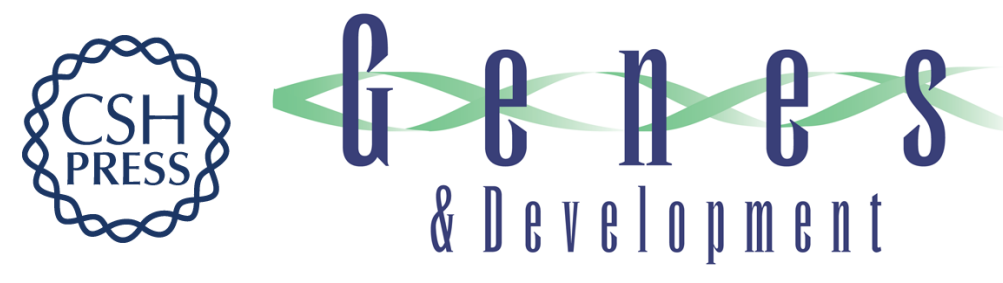

\section{The role of nuclear lamin B1 in cell proliferation and senescence}

Takeshi Shimi, Veronika Butin-Israeli, Stephen A. Adam, et al.

Genes Dev. 2011, 25: originally published online December 8, 2011

Access the most recent version at doi:10.1101/gad.179515.111

Supplemental

Material

References

\section{License}

Email Alerting Service
This article cites 96 articles, 49 of which can be accessed free at:

http://genesdev.cshlp.org/content/25/24/2579.full.html\#ref-list-1

http://genesdev.cshlp.org/content/suppl/2011/12/02/gad.179515.111.DC1

Receive free email alerts when new articles cite this article - sign up in the box at the top right corner of the article or click here.

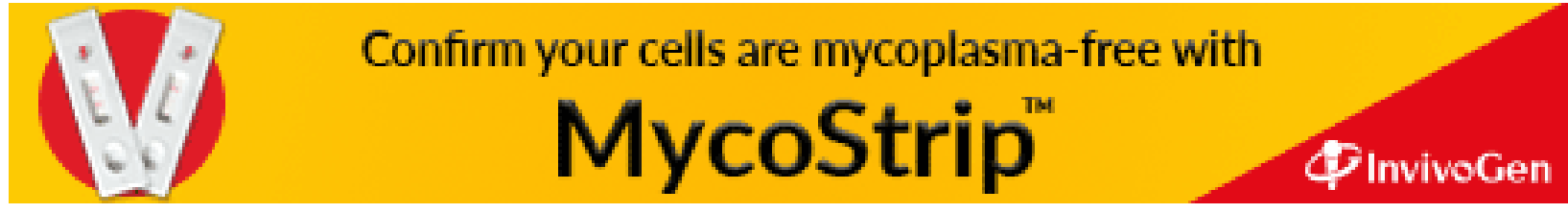

